\title{
A Synthetic Route to Benzothiazocines with Two or Three Carbon Stereocenters via Copper-Catalyzed Intramolecular $\mathrm{N}$-Arylation
}

\author{
Mickael Choury, ${ }^{[a]}$ Gaëlle Blond, ${ }^{[a]}$ and Mihaela Gulea*[a]
}

A new structural family of benzothiazocines bearing two or three carbon stereogenic centers on the 8-membered ring was synthesized by intramolecular $\mathrm{Cu}$-catalyzed $\mathrm{N}$-arylation. The chiral racemic 1,3-aminothioethers precursors have been prepared from easily available starting materials. An ionic organic base was used for the first time in an intramolecular $\mathrm{C}-\mathrm{N}$ coupling, in medium-ring series, leading to higher yields than those obtained with an inorganic base, and a partial epimerization in some cases. The synthetic sequence was successfully performed on one example in asymmetric version, demonstrating the accessibility of enantioenriched benzothiazocines.

\section{Introduction}

Among the large diversity of heterocyclic compounds, mediumsized heterocycles (8 to 11 atoms) represent a class of increasing interest due not only to their presence in bioactive natural products and pharmaceuticals but also because their syntheses still have challenges. Several reviews dealt with these aspects and the different approaches for the synthesis of these compounds. ${ }^{[1]}$ In particular, when intramolecular cyclizations are employed, enthalpic and entropic factors make the closing process difficult. In this context, we focused our recent research on benzothiazocines which are benzene-fused 8-membered ring $N, S$-heterocycles belonging to the class of medium-sized heterocycles. Although these scaffolds are present in some bioactive molecules, ${ }^{[2]}$ they are much less studied than their 5-, 6- and 7-membered N,S-heterocyclic counterparts (i.e. benzothiazoles, benzothiazines, benzothiazepines), which can be found in the list of the 362 sulfur-containing drugs approved by the FDA. ${ }^{[3]}$ One of the reasons may be the limited synthetic accessibility of these heterocycles and as a consequence their scarcity in chemical libraries for screening. The main methods to access benzothiazocines (Figure 1) include inter or intramolecular cyclization with $\mathrm{N}$ - and/or S-nucleophiles (i.e. SN2 reactions, amide bond formation), ${ }^{[4]}$ or intramolecular FriedelCrafts reaction. ${ }^{[5]}$ Some structures have been synthesized by benzyne ring closure ${ }^{[6]}$ ring-enlargement, ${ }^{[7]}$ or by Pd-catalyzed carbonylation reactions. ${ }^{[8]}$ Our group has recently reported the use of reductive carbopalladation to access benzimidazolefused benzothiazocines. ${ }^{[9,1 g]}$ On the other hand, most of the

[a] M. Choury, Dr. G. Blond, Dr. M. Gulea

CNRS, Laboratoire d'Innovation Thérapeutique, LIT UMR 7200, ITI InnoVec, Université de Strasbourg,

67000 Strasbourg, France

E-mail: gulea@unistra.fr

http://medchem.unistra.fr/synthese-organique-metallo-induite-et-heterochimie-somhet/membres/gulea-mihaela/

Supporting information for this article is available on the WWW under https://doi.org/10.1002/ejoc.202100305

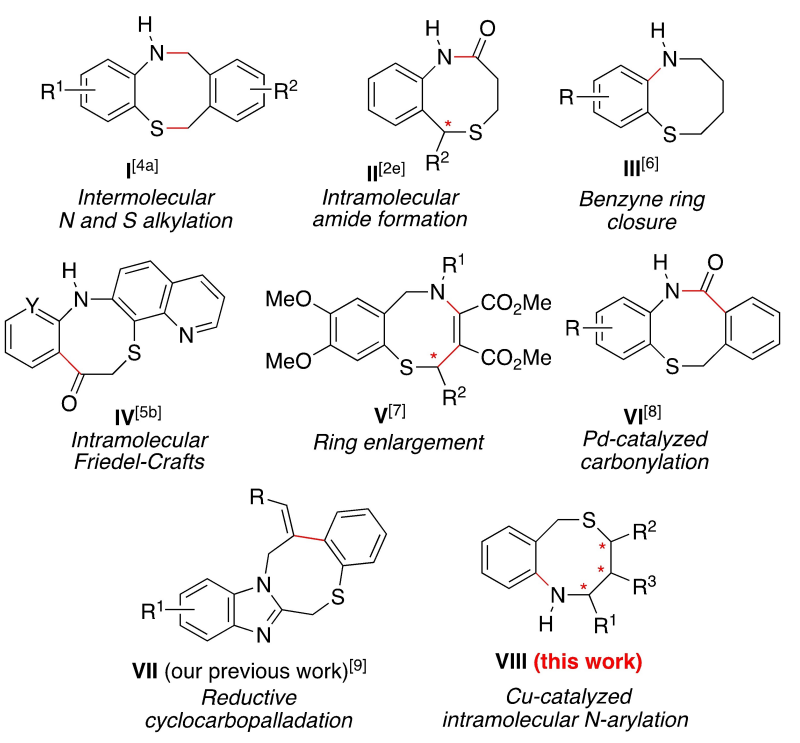

Figure 1. Structural diversity of benzothiazocines and key-step reactions for their synthesis (the corresponding formed bond is indicated in red).

published benzothiazocine structures are either achiral or racemic possessing one stereogenic carbon (Figure 1, I-VII).

This state-of-the-art of literature review prompted us to develop a method to access variously substituted benzothiazocines bearing two or three stereogenic carbons on the 8membered ring, thus increasing their bioactivity potential. ${ }^{[10]}$ We describe herein the synthesis of such benzothiazocines using intramolecular copper-catalyzed $\mathrm{N}$-arylation as the keystep (Figure 1, VIII).

The intramolecular $\mathrm{Cu}$-catalyzed $\mathrm{N}$-arylation represents a straightforward synthetic strategy to access a wide range of 5and 6-membered $\mathrm{N}$-heterocycles, ${ }^{[11]}$ however, to our knowledge, only very few examples have been described to obtain 8membered $\mathrm{N}$-heterocycles. ${ }^{[12,2 \mathrm{~h}]}$ The use of this approach for the cyclization of substrates such as substituted 1,3-aminothioethers is therefore not trivial. We can also mention that our 
previous attempts using intramolecular $N$-arylation under palladium-catalysis have all failed.

The synthesis of the target 5,1-benzothiazocines could be achieved starting from 1,3-aminothioethers having two or three controlled stereogenic centers (Scheme 1). Based on methodologies previously developed by some of $\mathrm{us}^{\left[{ }^{[13]}\right.}$ the suitable precursors may be accessible via ring-opening and subsequent S-benzylation from 1,3-thiazin-2-ones, which can be obtained in turn by a three-component hetero-Diels-Alder reaction.

\section{Results and Discussion}

We first prepared the racemic 1,3-aminothioether 3 a bearing on sulfur a 2-iodobenzyl group, as the model study substrate for the copper-catalyzed $\mathrm{N}$-arylation (Scheme 2).

The synthesis started with the three-component cycloaddition using $\mathrm{O}$-cyclohexyl thiocarbamate, benzaldehyde, and styrene. The major cis-cycloadduct 1 a was isolated, then transformed into its $\mathrm{N}$-Boc derivative $2 \mathrm{a}$. This was necessary to activate the 1,3-thiazin-2-one for the ring-opening step, preventing also the $\mathrm{N}$-alkylation during the next step. From $2 \mathrm{a}$ the transformation was achieved in three steps, ethanolysis, Salkylation, and Boc-deprotection. The desired product 3 a was obtained in a satisfactory overall yield of $55 \%$ as a single synstereoisomer.

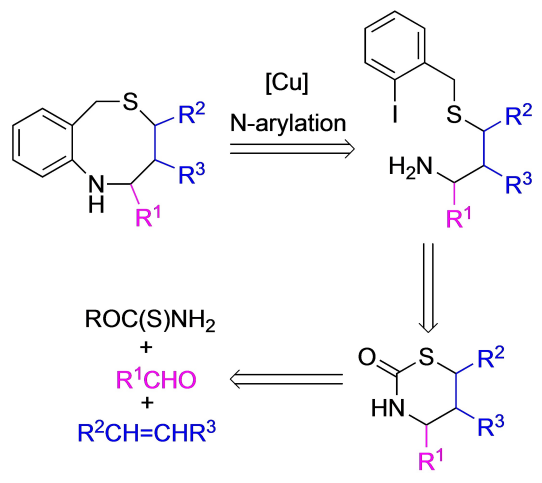

Scheme 1. Proposed retrosynthetic route to 5,1-benzothiazocines with 2 or 3 stereogenic centers via intramolecular $\mathrm{N}$-arylation.

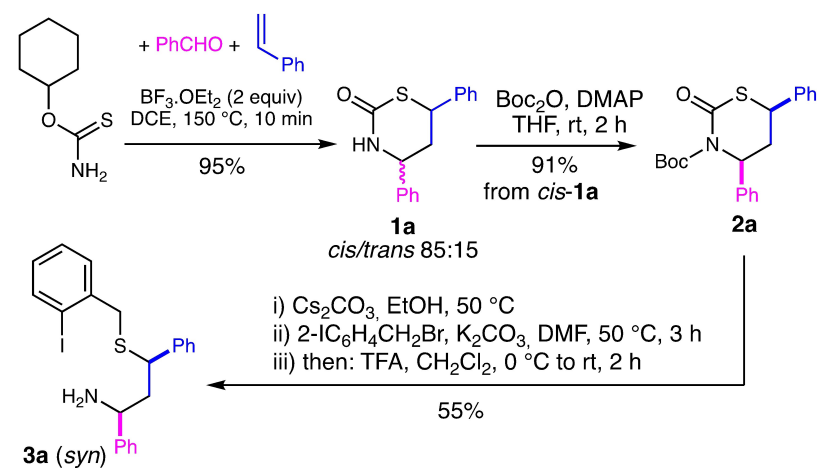

Scheme 2. Our general sequence accessing substrates 3 ; synthesis of $\mathbf{3} \mathbf{a}$.
We started with the optimization of the Cu-catalyzed intramolecular $\mathrm{N}$-arylation using substrate 3 a to obtain benzothiazocine 4 a (Table 1). A screening was conducted to identify the most suitable ligand/base combination.

The experiments were performed with copper iodide as the catalyst, in dimethylformamide, at $110^{\circ} \mathrm{C}$, for 40 hours. First, commonly used ligands L1-L7 in copper-catalyzed $\mathrm{C}-\mathrm{N}$ bond formation have been tested, keeping $\mathrm{K}_{3} \mathrm{PO}_{4}$ as the base (Table 1, entries 1-7). With 1,10-phenanthroline (L1) and $N, N^{\prime}$-dimethylethane-1,2-diamine (L2) the conversion was low, and the desired product $4 \mathrm{a}$ was obtained along with the hydrodehalogenated side-product $\mathbf{5} \mathbf{a},{ }^{,[14,15]}$ and isolated with yields below $10 \%$ (Table 1, entries 1 and 2). With $N, N^{\prime}$-dimethylcyclohexane1,2-diamine (L3) the conversion was increased, but more undesired $\mathbf{5}$ a was formed and the yield in $\mathbf{4}$ a was not improved (Table 1, entry 3). Ethylene glycol (L4) was used as both ligand and solvent leading to $4 \mathrm{a}$ in $17 \%$ yield (Table 1 , entry 4 ). A good result was obtained with $L$-proline (L5) (Table 1, entry 5). Under these conditions the conversion was total and although the formation of side-product $5 \mathrm{a}$ was not avoided (ratio $4 \mathrm{a} / 5 \mathrm{a}$ $2: 1)$, the desired product 4 a was isolated in $44 \%$ yield. Diketone-type ligands such 2-isobutyryl-cyclohexanone (L6) or pentane-2,4-dione (L7) did not give better results (Table 1, entries 6 and 7). A low conversion of $24 \%$ was obtained under ligand-free reaction conditions (Table 1 , entry 8 ). Working with

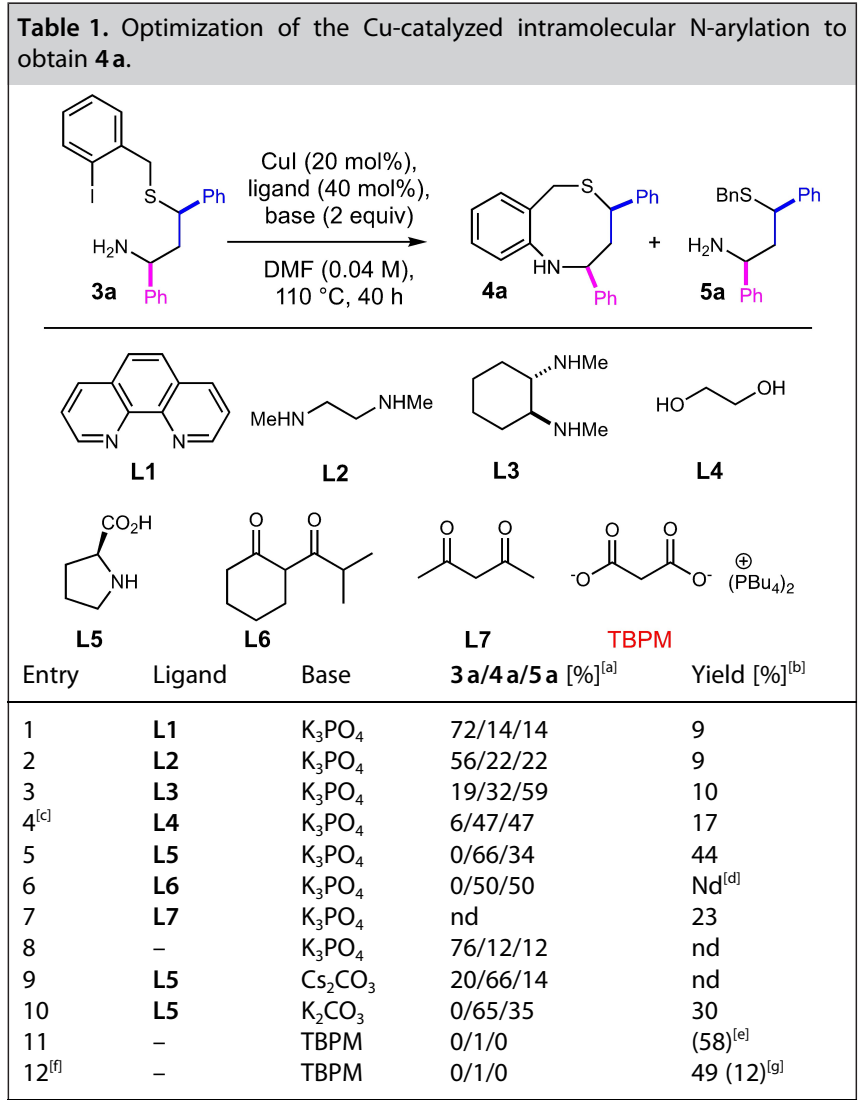

[a] Ratio measured by ${ }^{1} \mathrm{H}$ NMR in the crude mixture; [b] Iso-lated yield of $4 \mathrm{a}$; [c] L4 was used as the solvent instead of DMF; [d] Not determined; [e] Combined isolated yield of diastereomers $4 \mathrm{a}$ and $4^{\prime}$ a, ratio $4 \mathrm{a} / 4^{\prime}$ a 4 : 1 ; [f] Performed with Cul (10 mol\%); [g] In brackets, isolated yield of $4^{\prime}$ a. 
L5 using another base $\left(\mathrm{Cs}_{2} \mathrm{CO}_{3}\right.$ or $\mathrm{K}_{2} \mathrm{CO}_{3}$, Table 1, entries 9 and $10)$, temperature $\left(80^{\circ} \mathrm{C}, 130^{\circ} \mathrm{C}\right)$, solvent $(\mathrm{MeCN})$, or concentration, the yield dropped.

In $2009 \mathrm{Fu}$, Liu, and co-workers published a highly effective $\mathrm{Cu}$-catalyzed coupling of aryl iodides with amines by using ditetrabutylphosphonium malonate (TBPM) as an organic ionic soluble base. ${ }^{[16]}$ Then, in-depth mechanistic studies carried out by Davies and co-workers showed the ability of TBPM to serve as both base and ancillary $\mathrm{Cu}$-ligand for intermolecular $\mathrm{N}$ arylation. ${ }^{[17]}$ These interesting results prompted us to test TBPM in our reaction. Thus, under the same reaction conditions, TBPM was used as the base instead of the inorganic one, without adding a ligand (Table 1, entry 11). Two significant results were obtained: the competitive hydrodeiodination was suppressed (no trace of $\mathbf{5}$ a was observed) and the desired product 4 a was obtained along with its diastereomer $4^{\prime}$ a (phenyl substituents in trans), in a $4 \mathrm{a} / 4^{\prime}$ a ratio of $4: 1$ (measured by ${ }^{1} \mathrm{H}$ NMR in the crude mixture). The combined isolated yield of benzothiazocines $4 \mathrm{a}$ and $4^{\prime} \mathrm{a}$ was higher than the best result obtained previously ( $58 \%$ vs $44 \%$ ). We then decreased the catalytic charge to $10 \mathrm{~mol} \%$ Cul (Table 1, entry 12) and the diastereomeric products could be separated by column chromatography leading to $4 \mathrm{a}$ and $\mathbf{4}^{\prime} \mathrm{a}$ in $49 \%$ and $12 \%$ yield, respectively (combined yield: $61 \%$ ).

To explore the substrate scope and limitations, a range of 1,3-aminothioethers $\mathbf{3} \mathbf{b}-\mathbf{r}$ (Figure 2 ) was synthesized similarly to 3 a using different aldehydes and alkenes partners. Experimental details are given in SI. Styrene and norbornene have been selected due to their highly stereoselective cycloaddition, affording the corresponding 1,3-thiazin-2-ones 1 as major ciscycloadducts (1 $\mathbf{a}-\mathbf{l})$ or trans-cycloadducts (1 $\mathbf{n}-\mathbf{r})$, respectively. As the cis/trans stereoisomers of either from precursors 1 or 2 were separable, the corresponding aminothioethers $\mathbf{3}$ were obtained as a single stereoisomer, except the $\mathrm{NO}_{2}$-derivative $\mathbf{3 g}$ (ratio syn/anti 83:17). Cyclohexene led to a 60:40 cis/trans mixture of cycloadducts $1 \mathrm{~m} / 1^{\prime} \mathrm{m}$ from which we were able to obtain only the syn-product $3 \mathrm{~m}$. We did not exemplify on substrates having only alkyl substituents as the stereoselectivity

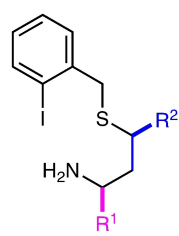

3a: $R^{1}=R^{2}=P h$

3b: $R^{1}=p-T o l, R^{2}=P h$

3c: $R^{1}=m-T o l, R^{2}=P h$

3d: $\mathrm{R}^{1}=4-\mathrm{MeO}-\mathrm{C}_{6} \mathrm{H}_{4}, \mathrm{R}^{2}=\mathrm{Ph}$

3e: $\mathrm{R}^{1}=4-\mathrm{Cl}-\mathrm{C}_{6} \mathrm{H}_{4}, \mathrm{R}^{2}=\mathrm{Ph}$

3f: $\mathrm{R}^{1}=4-\mathrm{F}-\mathrm{C}_{6} \mathrm{H}_{4}, \mathrm{R}^{2}=\mathrm{Ph}$

3g: $\mathrm{R}^{1}=4-\mathrm{NO}_{2}-\mathrm{C}_{6} \mathrm{H}_{4}, \mathrm{R}^{2}=\mathrm{Ph}$

3h: $\mathrm{R}^{1}=4-\mathrm{CF}_{3}-\mathrm{C}_{6} \mathrm{H}_{4}, \mathrm{R}^{2}=\mathrm{Ph}$

3i: $R^{1}=3-\mathrm{CF}_{3}-\mathrm{C}_{6} \mathrm{H}_{4}, \mathrm{R}^{2}=\mathrm{Ph}$

3j: $\mathrm{R}^{1}=\mathrm{Ph}, \mathrm{R}^{2}=4-\mathrm{Cl}-\mathrm{C}_{6} \mathrm{H}_{4}$

3k: $R^{1}=i P r, R^{2}=P h$

3l: $R^{1}=B n, R^{2}=P h$

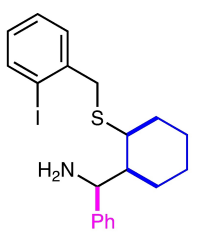

$3 \mathrm{~m}$

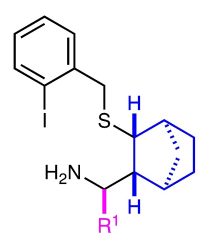

3n: $R^{1}=P h$

3o: $R^{1}=p$-Tol

3p: $\mathrm{R}^{1}=4-\mathrm{CF}_{3}-\mathrm{C}_{6} \mathrm{H}_{4}$

3q: $\mathrm{R}^{1}=3-\mathrm{CF}_{3}-\mathrm{C}_{6} \mathrm{H}_{4}$

3r: $\mathrm{R}^{1}=4-\mathrm{Br}-\mathrm{C}_{6} \mathrm{H}_{4}$
Figure 2. 1,3-Aminothioether substrates $3 a-r$. of the three-component reaction is low, making the stereoisomers separation difficult.

Considering the best results obtained in the optimization phase, we decided to use on the prepared substrates two sets of reaction conditions: one using $L$-proline (L5) as the ligand and $\mathrm{K}_{3} \mathrm{PO}_{4}$ as the base (Table 2 , conditions $\mathrm{A}$, in green) and the other using TBPM as both ligand and base (Table 2 , conditions $B$, in red). We first examined the influence of the electronic nature and position of the substituents on the aromatics in the cyclization of aminothioethers $\mathbf{3} \mathbf{b}-\mathbf{j}$ under conditions $A$. The substrates bearing in para or in meta positions electron donating (i.e. $\mathrm{Me}$ ) or electron-withdrawing groups (i.e. $\mathrm{Cl}, \mathrm{F}$, $\mathrm{CF}_{3}$ ), led to the desired products 4 accompanied by the corresponding by-products 5 in a ratio $4 / 5$ close to 2:1, however, we were able to isolate them with yields ranging from $18 \%$ to $47 \%$.

In the experiments involving substrates $\mathbf{3} \mathbf{d}$ and $\mathbf{3 g}$, we were not able to detect any of the known compounds (i.e. the starting material, the benzothiazocine, or the hydrodeiodinated product) in the crude mixture analyzed by ${ }^{1} \mathrm{H} N M R$, but only unidentified products. Then, substrates $\mathbf{3} \mathbf{k}$ and $\mathbf{3} \mathbf{n}$ bearing alkyl substituents have been placed under conditions $A$, leading to the expected products in respectively $40 \%$ and $64 \%$ yield. In these cases, we did not observe the corresponding undesired products $\mathbf{5 k}$ and $\mathbf{5 n}$. We next performed the reaction under conditions $\mathrm{B}$ for all synthesized substrates 3 . The set of results obtained showed the total suppression of the hydrodeiodination in all cases. As a consequence, benzothiazocines with two aryl substituents were obtained in higher yields than under conditions A. In these cases, the isolated yields represent the mixture of cis-4/trans-4' diastereomers with ratios ranging from $4: 1$ to $0.5 / 1$, but which are separable by column chromatography. With substrates $\mathbf{3} \mathbf{d}$ and $\mathbf{3} \mathbf{g}$ the reaction, unfortunately, failed again, with results similar to those obtained previously. Interestingly, starting from substrates bearing an isopropyl or a benzyl group next to the $\mathrm{N}$-atom (i.e. $\mathbf{3} \mathbf{k}, \mathbf{3 l}$ ), as well as from those containing a cycloalkane (i.e. $\mathbf{3} \mathbf{m}-\mathbf{r}$ ), the expected products $\mathbf{4 k - r}$ were obtained as a single diastereomer. In particular, norbornane benzothiazocines $4 \mathbf{n}-\mathbf{r}$ were isolated in good to excellent yields, with again a higher yield for $4 \mathrm{n}$ than that obtained under conditions A ( $98 \%$ vs. $64 \%$ ).

Noticeable, conditions B allowed obtaining product $4 \mathrm{r}$ having a bromophenyl substituent, without hydrodebromination. We also noticed that the cyclization of the aminothioethers with cycloalkane substituents $(\mathbf{3} \mathbf{m}-\mathbf{r})$ took place faster than the others (18 vs 40 hours). This could also explain the absence of hydrodeiodination under conditions $A$ in the case of $3 n$. An additional experiment was performed on substrate $\mathbf{3} \mathbf{b}$, keeping the ligand L5, but replacing the inorganic base with the ionic organic one. In this case, neither the hydrodeiodinated product 5b nor the epimer $\mathbf{4}^{\prime} \mathrm{b}$ was formed, and $\mathbf{4 b}$ was isolated in $50 \%$ yield (see in Table 2 ). In some cases $(\mathbf{4 h}, \mathbf{4 j}, \mathbf{4 l}, \mathbf{4 m}$ ), despite a total conversion, the isolated yields remained around $30 \%$. The crude mixture contained in these cases unidentified products and we could not explain this fact and improve the yields. 
Crystals obtained from 4b (CCDC 2042277), 4e (CCDC 2056458), 4f (CCDC 2042276), and 4n (CCDC 2042275) allowed to unambiguously assign their relative stereochemistry by X-ray crystallographic analysis (Figure 3 and SI).

A proposed reaction mechanism involving TBPM, based on the relevant literature, ${ }^{[17 b]}$ is given in Scheme 3 . The catalytic cycle may be similar to the general Ullmann-type $\mathrm{C}-\mathrm{N}$ coupling, with the dianionic malonate from TBPM acting as both the ancillary $\mathrm{Cu}$-ligand (in i1 intermediate) and base (for the $\mathrm{N}-\mathrm{H}$ deprotonation of $\mathbf{i} 1)$. The resulting species i2 represents the key catalytic intermediate and gives, via oxidative addition of the aryl iodide, species i3. Final reductive elimination affords

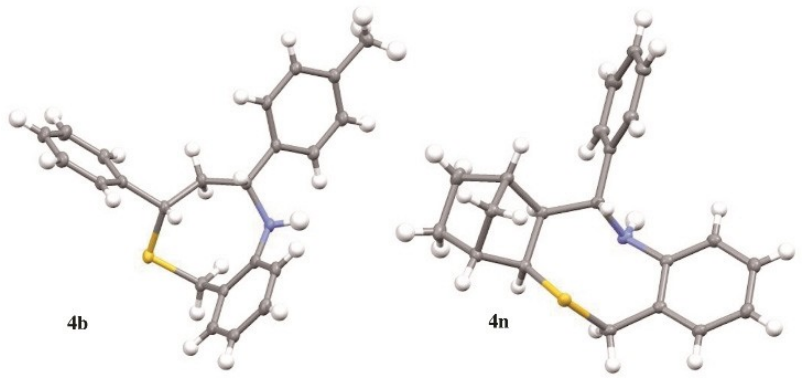

Figure 3. X-ray structures of benzothiazocines $4 \mathrm{~b}$ and $4 \mathrm{n}$ (50\% probability ellipsoids). arylamine product 4 and regenerates the $\mathrm{Cu}(\mathrm{I})$ catalytic complex.

On another hand, we wondered if the formation of $4^{\prime}$ under conditions $B$ took place before the cyclization, or after by partial epimerization of 4 . To check this, we first placed pure $4 \mathrm{a}$ in the reaction conditions (Scheme 3, Eq. 1). After 16 hours, the crude reaction mixture contained diastereomers $4 \mathrm{a}$ and $4^{\prime} \mathbf{a}$ in a ratio of $2: 1$. When pure $4^{\prime}$ a was submitted to the same test the starting material was recovered without epimerization (Scheme 3, Eq. 2). In the presence of TBPM, without copper iodide, 4 a was also epimerized, giving a $4 a / 4^{\prime}$ a ratio of $4: 1$ (Scheme 3, Eq. 3). Modification of the reaction time, of the temperature, or of the Cul or base charge, did not make significant changes to these results. We supposed that under the reaction conditions, a deprotonation/reprotonation occurred at one of the stereogenic centers leading to the more stable trans-isomer. In order to get more information, we placed the cis-isomer $\mathbf{4} \mathbf{b}$ under conditions $\mathbf{B}$ but using as the solvent $\mathbf{a}$ 9/1 mixture of DMF/ $\mathrm{D}_{2} \mathrm{O}$ (Scheme 4, Eq. 4). The epimerization took place leading to a mixture of $4 \mathrm{~b}$ and $4^{\prime} \mathrm{b}$ in $4: 1$ ratio, with a $50 \%$ deuterium incorporation on the formed trans-isomer $\mathbf{4}^{\prime} \mathbf{b}$, while $\mathbf{4 b}$ was recovered non-deuterated. The deuterium labeling was observed only at the 4-position (SCHPh), indicating that the stereogenic carbon next to the sulfur atom is the one, which epimerizes. In-depth studies will certainly be necessary to rationalize the epimerization induced by the use of TBPM. 


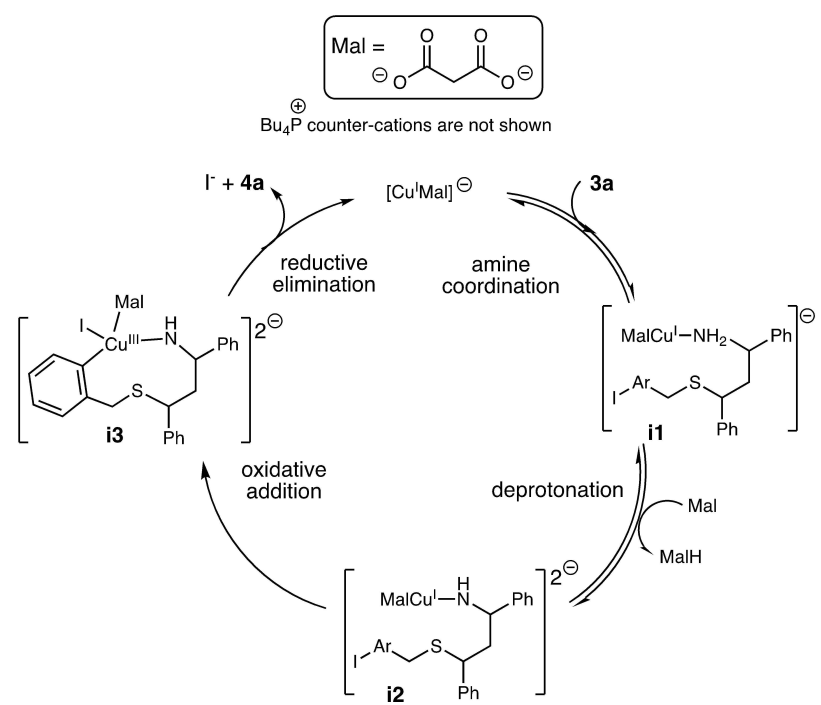

Scheme 3. Proposed reaction mechanism
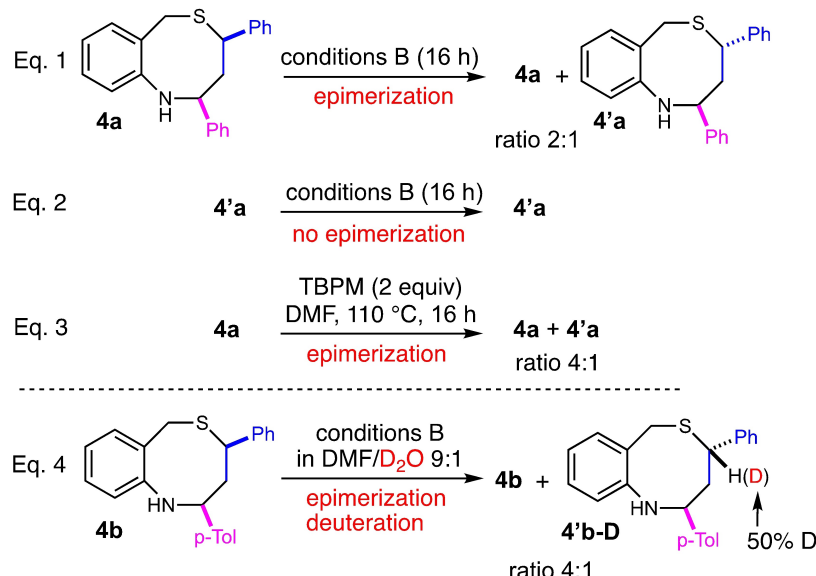

Scheme 4. Control experiments.

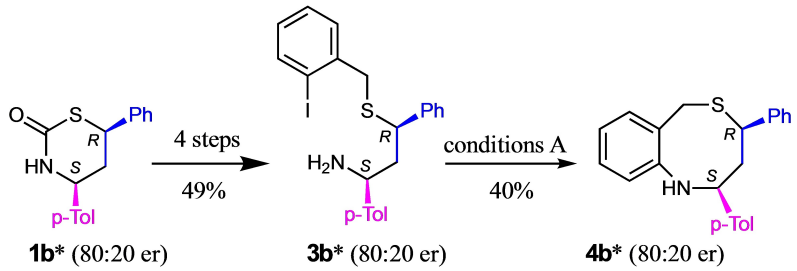

Scheme 5. Toward chiral non-racemic benzothiazocines (the major stereoisomers are illustrated)

We finally envisaged potential access to non-racemic benzothiazocines (Scheme 5). Starting from O-(L-menthyl) thiocarbamate, styrene, and para-tolyl aldehyde, 1,3-thiazin-2-one cis-1 $\mathbf{b}^{*}$ was obtained with an enantiomeric ratio (er) of $80: 20$ (measured by chiral HPLC). ${ }^{[18]}$ It should be noticed that $1,3-$ thiazin-2-ones with higher er (up to 97:3) can be prepared by using (-)-8-(2-naphthyl)menthol as the chiral auxiliary. ${ }^{[13 a]}$ Then, the same synthetic sequence previously used to access $\mathbf{3 b}$ enabled the transformation of $\mathbf{1} \mathbf{b}^{*}$ into $3 \mathbf{b}^{*}$ with preservation of the initial er (measured by derivatization using the Mosher's method $\left.{ }^{[19]}\right)$. The cyclization was performed under conditions A, leading to the enantioenriched benzothiazocine $\mathbf{4} b^{*}$ with an unchanged er of 80:20 (measured utilizing the $R$-(+)-tertbutylphenylphosphinothioic acid as a chiral solvating agent ${ }^{[20]}$ ). The $N$-arylation using the $L$-proline/TBPM combination led to a similar result.

\section{Conclusion}

In summary, we have developed a Cu-catalyzed $\mathrm{N}$-arylation to synthesize chiral racemic benzothiazocines bearing two or three stereogenic carbons on the 8-membered ring. Higher yields have been obtained when the reaction was performed using an ionic organic base (TBPM) instead of an inorganic base $\left(\mathrm{K}_{3} \mathrm{PO}_{4}\right)$. This represents also the first example of the use of an ionic organic base in $\mathrm{Cu}$-catalyzed intramolecular $\mathrm{C}-\mathrm{N}$ bond formation, moreover in the difficult case of medium-sized heterocycle series. In some cases, the use of TBPM prevented the undesired hydrodehalogenation, but induced a partial epimerization at the stereogenic carbon next to the sulfur atom of the heterocycle. Further studies will be conducted to rationalize this result. The example performed in non-racemic series allows us to validate the feasibility of the asymmetric synthesis of this new family of benzothiazocines. The overall synthetic sequence enables access to a large variety of new potentially active compounds, rare in chemical libraries.

\section{Experimental Section}

General Information: Reagents and dry solvents were obtained from commercial sources and used without further purification. Thin-layer chromatography (TLC) was performed on silica gel 60 F254 plates and was visualized under UV light and revealed with $\mathrm{KMnO} 4$ stain. Crude products were purified by flash column chromatography on Merck silica gel Si $60(40-63 \mu \mathrm{m})$ or by using a CombiFlash Rf (Teledyne Isco) system. NMR spectra were recorded at 400 or $500 \mathrm{MHz}$ for ${ }^{1} \mathrm{H}$, at 100 or $125 \mathrm{MHz}$ for ${ }^{13} \mathrm{C}$, and at $376 \mathrm{MHz}$ for ${ }^{19} \mathrm{~F}$. Chemical shifts $(\delta)$ were reported in ppm relative to residual solvent. Coupling constants $(J)$ were reported in hertz $(\mathrm{Hz})$. Assignments of ${ }^{1} \mathrm{H}$ and $13 \mathrm{C}$ signal were made by DEPT, COSY, HSQC, $\mathrm{HMBC}$, and NOESY-2D experiments. The following abbreviations were adopted in reporting NMR data: singlet (s), doublet (d), triplet $(\mathrm{t})$, quartet (q), quintet (quint), broad signal (bs), doublet of doublets (dd), doublet of doublet of doublets (ddd), doublet of triplets (dt), doublet of quartets $(\mathrm{dq})$, triplet of doublets $(\mathrm{td})$, triplet of triplets (tt), quartet of triplets (qt) or multiplet (m). HRMS were performed with a Q-TOF analyzer using electrospray ionization (ESI). Melting points were determined in open capillary tubes and were uncorrected. High-performance liquid chromatography (HPLC) separation of the enantioenriched $1 \mathbf{b}^{*}$ was achieved using a chromatograph constructed with the following components: a Waters 2795 pump, a Waters 996 photodiode array detector and Empower Software. The following column has been used: Chiralpak $^{\circledast}$ IB, a 3,5-dimethylphenylcarbamate derivative of cellulose, immobilized on $5 \mu \mathrm{m}$ silica gel. 
Typical procedures for the Cu-catalyzed cyclization; Synthesis of benzothiazocine $4 \mathrm{a}$

General Procedure A. Under argon, substrate 3 a $\quad(50 \mathrm{mg}$, $0.11 \mathrm{mmol}, 1$ equiv) was placed in a pressure tube. $\mathrm{K}_{3} \mathrm{PO}_{4}(46 \mathrm{mg}$, $0.22 \mathrm{mmol}, 2$ equiv), $L$-proline $(5 \mathrm{mg}, 0.044 \mathrm{mmol}, 0.4$ equiv), and Cul ( $4 \mathrm{mg}, 0.022 \mathrm{mmol}, 0.2$ equiv) were added. DMF $(0.04 \mathrm{M}$, $2.7 \mathrm{~mL}$ ) was added, the tube was sealed, and three freeze-thaw cycles are performed under stirring to degas the solvent. Under argon, the tube is heated in a $110^{\circ} \mathrm{C}$ oil-bath for 18 to $40 \mathrm{~h}$. After reaching room temperature, volatiles were removed by vacuum, the crude was diluted with AcOEt, filtered through basic alumina, then the solvent was removed. The crude mixture (containing $4 \mathrm{a}$ and $5 \mathrm{a}$ in a ratio of $2: 1$ ) was purified by flash chromatography with heptane/AcOEt (95/5) to give product 4 a (16 mg, $0.05 \mathrm{mmol}, 44 \%)$ as a white amorphous solid.

General Procedure B. Under argon, substrate 3 a $(60 \mathrm{mg}$, $0.13 \mathrm{mmol}, 1$ equiv) was placed in a pressure tube. TBPM (161 mg, $0.2 \mathrm{mmol}, 2$ equiv) and Cul ( $2.5 \mathrm{mg}, 0.013 \mathrm{mmol}, 0.1$ equiv) were added. DMF $(0.04 \mathrm{M}, 3.2 \mathrm{~mL})$ was added, the tube was sealed, and three freeze-thaw cycles are performed under stirring to degas the solvent. Under argon, the tube is heated in a $110^{\circ} \mathrm{C}$ oil-bath for 18 to $40 \mathrm{~h}$. The work-up was identical to that of procedure A. Products 4 a (21 mg, $0.064 \mathrm{mmol}, 49 \%$ ) and 4' a (5 mg, $0.016 \mathrm{mmol}, 12 \%)$ have been obtained as white amorphous solids.

\section{2,4-diphenyl-1,3,4,6-tetrahydro-2H-benzo[c][1,5]thiazocine (4a)}

Following the general procedure $A$, starting from substrate $3 \mathrm{a}$ ( $50 \mathrm{mg}, 0.11 \mathrm{mmol})$, product $4 \mathrm{a}(16 \mathrm{mg}, 0.05 \mathrm{mmol}, 44 \%)$ has been obtained as a white amorphous solid. TLC (heptane/AcOEt 95/05, $\mathrm{Rf}=0.20)$.

Following the general procedure $B$, starting from substrate $3 \mathrm{a}$ (60 $\mathrm{mg}, 0.13 \mathrm{mmol})$, products 4 a $(21 \mathrm{mg}, 0.064 \mathrm{mmol}, 49 \%)$ and 4' a (5 mg, $0.016 \mathrm{mmol}, 12 \%)$ have been obtained as white amorphous solids.

4a: ${ }^{1} \mathrm{H}$ NMR $\left(400 \mathrm{MHz}, \mathrm{CDCl}_{3}\right) \delta$ 7.47-7.10 $(\mathrm{m}, 13 \mathrm{H}), 6.98-6.71(\mathrm{~m}$, $1 \mathrm{H}), 4.60\left(\mathrm{~d}, J=13.2 \mathrm{~Hz}, 1 \mathrm{H}, \mathrm{SCH}_{2}\right), 4.10(\mathrm{dd}, J=11.3,2.1 \mathrm{~Hz}, 1 \mathrm{H}$, $\mathrm{NCH}), 3.76\left(\mathrm{~d}, J=13.2 \mathrm{~Hz}, 1 \mathrm{H}, \mathrm{SCH}_{2}\right), 3.63(\mathrm{dd}, J=7.0,2.1 \mathrm{~Hz}, 1 \mathrm{H}$, $\mathrm{SCH}), 2.85\left(\mathrm{ddd}, J=15.3,11.2,7.0 \mathrm{~Hz}, 1 \mathrm{H}, \mathrm{CH}_{2}\right), 2.58(\mathrm{dt}, J=15.3$, $\left.2.1 \mathrm{~Hz}, 1 \mathrm{H}, \mathrm{CH}_{2}\right) .{ }^{13} \mathrm{C}$ NMR $\left(101 \mathrm{MHz}, \mathrm{CDCl}_{3}\right) \delta 146.3,145.0,142.3$, $134.2,132.8,130.2,129.0,128.8(2 \mathrm{C}), 128.7(2 \mathrm{C}), 128.6(2 \mathrm{C}), 128.2$, 127.7, $126.5(2 \mathrm{C}), 125.6,125.5,66.1(\mathrm{NCH}), 49.4\left(\mathrm{CH}_{2}\right), 46.1(\mathrm{SCH})$, $32.7\left(\mathrm{SCH}_{2}\right)$. HRMS (ESI-Q-TOF) $\mathrm{m} / \mathrm{z}$ calcd for $\mathrm{C}_{22} \mathrm{H}_{22} \mathrm{NS}[\mathrm{M}+\mathrm{H}]^{+}$: 332.1467 , found: 332.1468 .

4' a: ${ }^{1} \mathrm{H}$ NMR $\left(400 \mathrm{MHz}, \mathrm{CDCl}_{3}\right) \delta 7.50-7.45(\mathrm{~m}, 2 \mathrm{H}), 7.41-7.35(\mathrm{~m}$, $2 \mathrm{H}), 7.34-7.28(\mathrm{~m}, 1 \mathrm{H}), 7.24-7.12(\mathrm{~m}, 5 \mathrm{H}), 7.10-7.06(\mathrm{~m}, 2 \mathrm{H}), 6.99(\mathrm{td}$, $J=7.4,1.3 \mathrm{~Hz}, 1 \mathrm{H}), 6.82(\mathrm{dd}, J=7.8,1.4 \mathrm{~Hz}, 1 \mathrm{H}), 5.11(\mathrm{t}, J=5.8 \mathrm{~Hz}$, $1 \mathrm{H}, \mathrm{NCH}), 4.38(\mathrm{t}, J=6.5 \mathrm{~Hz}, 1 \mathrm{H}, \mathrm{SCH}), 4.23\left(\mathrm{~s}, 2 \mathrm{H}, \mathrm{SCH}_{2}\right), 2.75-2.29$ $\left(\mathrm{m}, 2 \mathrm{H}, \mathrm{CH}_{2}\right) .{ }^{13} \mathrm{C}$ NMR $\left(101 \mathrm{MHz}, \mathrm{CDCl}_{3}\right) \delta 147.3,143.3,143.2,131.4$, $128.8(2 \mathrm{C}), 128.6(2 \mathrm{C}), 128.2,127.6,127.3(2 \mathrm{C}), 127.0,126.9(2 \mathrm{C})$, $122.7,122.3,61.9(\mathrm{NCH}), 47.4\left(\mathrm{CH}_{2}\right), 47.0(\mathrm{SCH}), 36.9\left(\mathrm{SCH}_{2}\right)$.

\section{4-phenyl-2-(p-tolyl)-1,3,4,6-tetrahydro-2H-benzo[c][1,5] thiazocine $(4 \mathrm{~b})$}

Following the general procedure $A$, starting from substrate $3 \mathrm{~b}$ $(64 \mathrm{mg}, 0.14 \mathrm{mmol})$, product $4 \mathrm{~b}(22 \mathrm{mg}, 0.06 \mathrm{mmol}, 47 \%)$ has been obtained as a white amorphous solid. Recrystallization in $\mathrm{CDCl}_{3}$ gave colorless crystals $\left(\mathrm{Mp}=141^{\circ} \mathrm{C}\right.$ ). TLC (heptane/AcOEt 95/05, $\mathrm{Rf}=0.22$ )
Following the general procedure $B$, starting from substrate $3 \mathbf{b}$ ( $65 \mathrm{mg}, 0.14 \mathrm{mmol})$, products $4 \mathbf{b}(28 \mathrm{mg}, 0.08 \mathrm{mmol}, 59 \%)$ and $4^{\prime} \mathbf{b}$ ( $7 \mathrm{mg}, 0.02 \mathrm{mmol}, 15 \%$ ) have been obtained as white amorphous solids.

${ }^{1} \mathrm{H}$ NMR $\left(400 \mathrm{MHz}, \mathrm{CDCl}_{3}\right) \delta 7.37-7.34(\mathrm{~m}, 1 \mathrm{H}), 7.32-7.26(\mathrm{~m}, 2 \mathrm{H})$, 7.24-7.13 (m, 9H), 6.92-6.82 (m, 1H), $4.60\left(\mathrm{~d}, J=13.2 \mathrm{~Hz}, 1 \mathrm{H}, \mathrm{SCH}_{2}\right)$, $4.07(\mathrm{dd}, J=11.2,2.1 \mathrm{~Hz}, 1 \mathrm{H}, \mathrm{NCH}), 3.75\left(\mathrm{~d}, J=13.2 \mathrm{~Hz}, 1 \mathrm{H}, \mathrm{SCH}_{2}\right)$, $3.62(\mathrm{dd}, J=7.0,2.1 \mathrm{~Hz}, 1 \mathrm{H}, \mathrm{SCH}), 2.84$ (ddd, $J=15.3,11.2,7.0 \mathrm{~Hz}$, $\left.1 \mathrm{H}, \mathrm{CH}_{2}\right), 2.56\left(\mathrm{dt}, J=15.3,2.1 \mathrm{~Hz}, 1 \mathrm{H}, \mathrm{CH}_{2}\right), 2.34(\mathrm{~s}, 3 \mathrm{H}) .{ }^{13} \mathrm{C}$ NMR $\left(101 \mathrm{MHz}, \mathrm{CDCl}_{3}\right) \delta 146.5,143.8,142.3,137.2,134.2,130.2,129.4$ (2C), 128.5 (2C), 128.1, $127.6(2 \mathrm{C}), 127.1,126.4(2 \mathrm{C}), 125.5,125.3$, $65.8(\mathrm{NCH}), 49.5\left(\mathrm{CH}_{2}\right), 46.8(\mathrm{SCH}), 32.8\left(\mathrm{SCH}_{2}\right), 21.1\left(\mathrm{CH}_{3}\right)$. HRMS (ESI-Q-TOF) $\mathrm{m} / \mathrm{z}$ calcd for $\mathrm{C}_{23} \mathrm{H}_{24} \mathrm{NS}[\mathrm{M}+\mathrm{H}]^{+}:$346.1624, found: 346.1634.

4' b: ${ }^{1} \mathbf{H}$ NMR $\left(400 \mathrm{MHz}, \mathrm{CDCl}_{3}\right) \delta 7.38-7.31(\mathrm{~m}, 2 \mathrm{H}), 7.26-7.08(\mathrm{~m}$, $8 \mathrm{H}), 6.96(\mathrm{td}, J=7.5,1.3 \mathrm{~Hz}, 1 \mathrm{H}), 6.78(\mathrm{dd}, J=7.8,1.3 \mathrm{~Hz}, 1 \mathrm{H}), 5.13$ (dd, $J=7.5,4.6 \mathrm{~Hz}, 1 \mathrm{H}, \mathrm{NCH}), 4.38(\mathrm{dd}, J=8.8,4.6 \mathrm{~Hz}, 1 \mathrm{H}, \mathrm{SCH}), 4.28$ $\left(\mathrm{d}, J=13.6 \mathrm{~Hz}, 1 \mathrm{H}, \mathrm{SCH}_{2}\right), 4.17\left(\mathrm{~d}, J=13.6 \mathrm{~Hz}, 1 \mathrm{H}, \mathrm{SCH}_{2}\right), 3.37(\mathrm{bs}, 1 \mathrm{H}$, $\mathrm{NH}), 2.54-2.48\left(\mathrm{~m}, 2 \mathrm{H}, \mathrm{CH}_{2}\right), 2.36\left(\mathrm{~s}, 3 \mathrm{H}, \mathrm{CH}_{3}\right) .{ }^{13} \mathrm{C}$ NMR $(101 \mathrm{MHz}$, $\left.\mathrm{CDCl}_{3}\right) \delta 147.5,143.0,140.4,137.3,131.5,129.4(2 \mathrm{C}), 128.5(2 \mathrm{C})$, $128.2,127.4(2 \mathrm{C}), 127.0,126.8(2 \mathrm{C}), 122.3,121.8,61.4(\mathrm{NCH}), 47.6$ $\left(\mathrm{CH}_{2}\right), 47.1(\mathrm{SCH}), 37.1\left(\mathrm{SCH}_{2}\right), 21.1\left(\mathrm{CH}_{3}\right)$. HRMS (ESI-Q-TOF) $\mathrm{m} / \mathrm{z}$ calcd for $\mathrm{C}_{23} \mathrm{H}_{24} \mathrm{NS}[\mathrm{M}+\mathrm{H}]^{+}$: 346.1624 , found: 346.1633

\section{4-phenyl-2-(m-tolyl)-1,3,4,6-tetrahydro-2H-benzo[c][1,5] thiazocine $(4 \mathrm{c})$}

Following the general procedure $A$, starting from substrate $3 \mathrm{c}$ (64 mg, $0.14 \mathrm{mmol})$, product 4c (20 mg, $0.06 \mathrm{mmol}, 43 \%)$ has been obtained as an colorless oil. TLC (heptane/AcOEt 95/05, Rf =0.22).

Following the general procedure $B$, starting from substrate $3 \mathrm{C}$ $(100 \mathrm{mg}, 0.21 \mathrm{mmol})$, a mixture of products $4 \mathrm{c}$ and $4^{\prime} \mathrm{c}(49 \mathrm{mg}$, $0.14 \mathrm{mmol}, 67 \%$, ratio $1: 0.25)$ have been obtained as a colorless oil. ${ }^{1} \mathrm{H}$ NMR $\left(400 \mathrm{MHz}, \mathrm{CDCl}_{3}\right) \delta$ 7.43-7.39 $(\mathrm{m}, 1 \mathrm{H}), 7.31-7.19(\mathrm{~m}, 11 \mathrm{H})$, $7.17-7.12(\mathrm{~m}, 1 \mathrm{H}), 6.93(\mathrm{dd}, J=7.4,1.8 \mathrm{~Hz}, 1 \mathrm{H}), 4.67(\mathrm{~d}, J=13.1 \mathrm{~Hz}$, $\left.1 \mathrm{H}_{1} \mathrm{SCH}_{2}\right), 4.10(\mathrm{dd}, J=11.2,2.1 \mathrm{~Hz}, 1 \mathrm{H}, \mathrm{NCH}), 3.79(\mathrm{~d}, J=13.1 \mathrm{~Hz}$, $\left.1 \mathrm{H}, \mathrm{SCH}_{2}\right), 3.65$ (dd, $\left.J=7.0,2.1 \mathrm{~Hz}, 1 \mathrm{H}, \mathrm{SCH}\right), 3.37$ (bs, $\left.1 \mathrm{H}, \mathrm{NH}\right), 2.90$ (ddd, $\left.J=15.3,11.2,7.0 \mathrm{~Hz}, 1 \mathrm{H}, \mathrm{CH}_{2}\right), 2.62(\mathrm{dt}, J=15.3,2.1 \mathrm{~Hz}, 1 \mathrm{H}$, $\left.\mathrm{CH}_{2}\right), 2.41\left(\mathrm{~s}, 3 \mathrm{H}, \mathrm{CH}_{3}\right) .{ }^{13} \mathrm{C}$ NMR $\left(101 \mathrm{MHz}, \mathrm{CDCl}_{3}\right) \delta 146.5,145.2$, $143.8,138.5,134.2,130.2,128.7,128.5(2 \mathrm{C}), 128.3,128.2,127.6(2 \mathrm{C})$, $127.2,127.1,125.4,125.3,123.5,66.2(\mathrm{NCH}), 49.6\left(\mathrm{CH}_{2}\right), 46.8(\mathrm{SCH})$, $32.7\left(\mathrm{SCH}_{2}\right), 21.5\left(\mathrm{CH}_{3}\right)$. HRMS (ESI-Q-TOF) $\mathrm{m} / \mathrm{z}$ calcd for $\mathrm{C}_{23} \mathrm{H}_{24} \mathrm{NS}[\mathrm{M}$ $+\mathrm{H}]^{+}$: 346.1624, found: 346.1642 .

\section{2-(4-chlorophenyl)-4-phenyl-1,3,4,6-tetrahydro-2H-benzo $[c][1,5]$ thiazocine $(4 \mathrm{e})$}

Following the general procedure $A$, starting from substrate $3 \mathrm{e}$ ( $60 \mathrm{mg}, 0.12 \mathrm{mmol})$, product 4 e $(16 \mathrm{mg}, 0.04 \mathrm{mmol}, 35 \%)$ has been obtained as a yellow oil. Recrystallization in $\mathrm{CDCl}_{3}$ gave colorless crystals $\left(\mathrm{Mp}=170^{\circ} \mathrm{C}\right) . \mathrm{TLC}$ (heptane/AcOEt 95/05, Rf $=0.16$ ).

Following the general procedure $B$, starting from substrate $3 \mathbf{e}$ $(60 \mathrm{mg}, 0.12 \mathrm{mmol})$, a mixture of products $4 \mathrm{e}$ and $4^{\prime} \mathrm{e}(30 \mathrm{mg}$, $0.08 \mathrm{mmol}, 67 \%$, ratio $1: 0.25)$ have been obtained as a yellow oil. 'H NMR $\left(400 \mathrm{MHz} \mathrm{CDCl}_{3}\right) \delta 7.38-7.33(\mathrm{~m}, 1 \mathrm{H}), 7.32(\mathrm{~s}, 4 \mathrm{H}), 7.25-7.14$ (m, 7H), 6.88-6.81 (m, 1H), $4.54\left(\mathrm{~d}, J=13.2 \mathrm{~Hz}, 1 \mathrm{H}, \mathrm{SCH}_{2}\right), 4.08(\mathrm{dd}$, $J=11.4,2.2 \mathrm{~Hz}, 1 \mathrm{H}, \mathrm{NCH}), 3.78\left(\mathrm{~d}, J=13.2 \mathrm{~Hz}, 1 \mathrm{H}, \mathrm{SCH}_{2}\right), 3.62(\mathrm{dd}$, $J=6.8,2.2 \mathrm{~Hz}, 1 \mathrm{H}, \mathrm{SCH}$ ), 2.80 (ddd, $J=15.2,11.4,6.8 \mathrm{~Hz}, 1 \mathrm{H}, \mathrm{CH}_{2}$ ), $2.53\left(\mathrm{dt}, J=15.3,2.2 \mathrm{~Hz}, 1 \mathrm{H}, \mathrm{CH}_{2}\right) .{ }^{13} \mathrm{C}$ NMR $\left(101 \mathrm{MHz}, \mathrm{CDCl}_{3}\right) \delta$ $145.9,143.7,143.5,134.5,133.2,130.2,128.9$ (2C), 128.6 (2C), 128.2, $127.9(2 \mathrm{C}), 127.6(2 \mathrm{C}), 127.2,125.7,125.6,65.3(\mathrm{NCH}), 49.2\left(\mathrm{CH}_{2}\right)$, $46.7(\mathrm{SCH}), 32.8\left(\mathrm{SCH}_{2}\right)$. 


\section{2-(4-fluorophenyl)-4-phenyl-1,3,4,6-tetrahydro-2H-benzo $[c][1,5]$ thiazocine $(4 \mathrm{f})$}

Following the general procedure $A$, starting from substrate $3 f$ (50 $\mathrm{mg}, 0.11 \mathrm{mmol})$, product $4 \mathrm{f}(12 \mathrm{mg}, 0.03 \mathrm{mmol}, 33 \%)$ has been obtained as a white amorphous solid Recrystallization in $\mathrm{CDCl}_{3}$ gave colorless crystals $\left(\mathrm{Mp}=142^{\circ} \mathrm{C}\right.$ ). TLC (heptane/AcOEt $95 / 05$, $\mathrm{Rf}=0.22$ )

Following the general procedure $B$, starting from substrate $3 f$ ( $24 \mathrm{mg}, 0.05 \mathrm{mmol})$, a mixture of products $4 \mathrm{f}$ and $\mathbf{4}^{\prime} \mathrm{f}(14 \mathrm{mg}$, $0.04 \mathrm{mmol}, 80 \%$, ratio 1:0.25) have been obtained as a colorless oil. ${ }^{1} \mathrm{H}$ NMR $\left(400 \mathrm{MHz}, \mathrm{CDCl}_{3}\right) \delta 7.35$ (ddd, $\left.J=8.9,4.6,2.0 \mathrm{~Hz}, 3 \mathrm{H}\right), 7.25-$ $7.14(\mathrm{~m}, 7 \mathrm{H}), 7.08-6.98(\mathrm{~m}, 2 \mathrm{H}), 6.90-6.81(\mathrm{~m}, 1 \mathrm{H}), 4.55(\mathrm{~d}, J=$ $\left.13.2 \mathrm{~Hz}, 1 \mathrm{H}, \mathrm{SCH}_{2}\right), 4.09$ (dd, $\left.J=11.4,2.2 \mathrm{~Hz}, 1 \mathrm{H}, \mathrm{NCH}\right), 3.77(\mathrm{~d}, J=$ $13.2 \mathrm{~Hz}, 1 \mathrm{H}, \mathrm{SCH}_{2}$ ), 3.62 (dd, $J=6.9,2.2 \mathrm{~Hz}, 1 \mathrm{H}, \mathrm{SCH}$ ), 2.81 (ddd, $J=$ $\left.15.3,11.4,6.9 \mathrm{~Hz}, 1 \mathrm{H}, \mathrm{CH}_{2}\right), 2.54\left(\mathrm{dt}, J=15.3,2.2 \mathrm{~Hz}, 1 \mathrm{H}, \mathrm{CH}_{2}\right) .{ }^{13} \mathrm{C}$ NMR $\left(101 \mathrm{MHz} \mathrm{CDCl}_{3}\right) \delta 162.1(\mathrm{~d}, J=245.8 \mathrm{~Hz}), 146.0,143.8,140.9$ (d, J=3.3 Hz), 134.5, 130.2, $128.6(2 \mathrm{C}), 128.1(2 \mathrm{C}), 128.1,127.6(2 \mathrm{C})$, 127.2, 125.7, 125.5, $115.5(\mathrm{~d}, J=21.3 \mathrm{~Hz}, 2 \mathrm{C}), 65.3(\mathrm{NCH}), 49.4\left(\mathrm{CH}_{2}\right)$, $46.7(\mathrm{SCH}), 32.7\left(\mathrm{SCH}_{2}\right) .{ }^{19} \mathrm{~F}$ NMR $\left(376 \mathrm{MHz}, \mathrm{CDCl}_{3}\right) \delta-114.9$.

\section{4-phenyl-2-(4-(trifluoromethyl)phenyl)-1,3,4,6-tetrahydro- $2 \mathrm{H}$ - benzo[c][1,5]thiazocine $(4 \mathrm{~h})$}

Following the general procedure $A$, starting from substrate $3 \mathrm{~h}$ $(100 \mathrm{mg}, 0.19 \mathrm{mmol})$, product $4 \mathrm{~h}(14 \mathrm{mg}, 0.03 \mathrm{mmol}, 18 \%)$ has been obtained as a colorless oil. TLC (heptane/AcOEt 95/05, Rf= 0.18).

Following the general procedure $B$, starting from substrate $3 \mathrm{~h}$ ( $88 \mathrm{mg}, 0.17 \mathrm{mmol})$, a mixture of products $4 \mathrm{~h}$ and $4^{\prime} \mathrm{h}(16 \mathrm{mg}$, $0.04 \mathrm{mmol}, 24 \%$, ratio $1: 0.6)$ have been obtained as a colorless oil. ${ }^{1} \mathrm{H}$ NMR $\left(500 \mathrm{MHz}, \mathrm{CDCl}_{3}\right) \delta 7.61(\mathrm{~d}, J=8.3 \mathrm{~Hz}, 2 \mathrm{H}), 7.51(\mathrm{~d}, J=$ $8.3 \mathrm{~Hz}, 2 \mathrm{H}), 7.40-7.32(\mathrm{~m}, 1 \mathrm{H}), 7.27-7.13(\mathrm{~m}, 7 \mathrm{H}), 6.89-6.82(\mathrm{~m}, 1 \mathrm{H})$, $4.56\left(\mathrm{~d}, J=13.1 \mathrm{~Hz}, 1 \mathrm{H}, \mathrm{SCH}_{2}\right), 4.17(\mathrm{dd}, J=11.4,2.2 \mathrm{~Hz}, 1 \mathrm{H}, \mathrm{NCH})$, $3.78\left(\mathrm{~d}, J=13.1 \mathrm{~Hz}, 1 \mathrm{H}, \mathrm{SCH}_{2}\right), 3.63(\mathrm{dd}, J=7.0,2.2 \mathrm{~Hz}, 1 \mathrm{H}, \mathrm{SCH}), 2.82$ (ddd, $\left.J=15.3,11.4,7.0 \mathrm{~Hz}, 1 \mathrm{H}, \mathrm{CH}_{2}\right), 2.56(\mathrm{dt}, J=15.3,2.2 \mathrm{~Hz}, 1 \mathrm{H}$, $\left.\mathrm{CH}_{2}\right) .{ }^{13} \mathrm{C}$ NMR $\left(126 \mathrm{MHz}, \mathrm{CDCl}_{3}\right) \delta 148.7,145.9,143.6,134.4,130.3$, $129.8(q, J=32.7 \mathrm{~Hz}), 128.6(2 \mathrm{C}), 128.3,127.5(2 \mathrm{C}), 127.2,126.9(2 \mathrm{C})$, $125.8(\mathrm{q}, J=3.6 \mathrm{~Hz}, 2 \mathrm{C}), 125.7,125.6,124.1(\mathrm{q}, J=272.0 \mathrm{~Hz}), 65.6$ ( $\mathrm{NCH}), 49.3\left(\mathrm{CH}_{2}\right), 46.6(\mathrm{SCH}), 32.7\left(\mathrm{SCH}_{2}\right) .{ }^{19} \mathrm{~F} \mathrm{NMR}\left(376 \mathrm{MHz}, \mathrm{CDCl}_{3}\right)$ $\delta$-62.5. HRMS (ESI-Q-TOF) $\mathrm{m} / \mathrm{z}$ calcd for $\mathrm{C}_{23} \mathrm{H}_{21} \mathrm{~F}_{3} \mathrm{NS}[\mathrm{M}+\mathrm{H}]^{+}$: 400.1341, found: 400.1358 .

\section{4-phenyl-2-(3-(trifluoromethyl)phenyl)-1,3,4,6-tetrahydro-2H-} benzo[c][1,5]thiazocine (4i)

Following the general procedure $A$, starting from substrate $3 \mathbf{i}$ (63 mg, $0.12 \mathrm{mmol}$ ), product 4 i (16 $\mathrm{mg}, 0.04 \mathrm{mmol}, 34 \%$ ) has been obtained as a colorless oil. TLC (heptane/AcOEt 95/05, Rf $=0.18$ ).

Following the general procedure $B$, starting from substrate $3 \mathbf{i}$ $(60 \mathrm{mg}, 0.11 \mathrm{mmol})$, a mixture of products $4 \mathbf{i}$ and $4^{\prime} \mathbf{i}(27 \mathrm{mg}$, $0.07 \mathrm{mmol}, 59 \%$, ratio $1: 0.25)$ have been obtained as a colorless oil. ${ }^{1} \mathrm{H}$ NMR $\left(400 \mathrm{MHz}, \mathrm{CDCl}_{3}\right)$ \& 7.67-7.64 $(\mathrm{m}, 1 \mathrm{H}), 7.60-7.53(\mathrm{~m}, 2 \mathrm{H})$, 7.50-7.45 (m, 1H), 7.40-7.36 (m, 1H), 7.27-7.16 (m, 7H), 6.91-6.82 $(\mathrm{m}, 1 \mathrm{H}), 4.57\left(\mathrm{~d}, J=13.2 \mathrm{~Hz}, 1 \mathrm{H}, \mathrm{SCH}_{2}\right), 4.17(\mathrm{dd}, J=11.4,2.2 \mathrm{~Hz}, 1 \mathrm{H}$, $\mathrm{NCH}), 3.78\left(\mathrm{~d}, J=13.2 \mathrm{~Hz}, 1 \mathrm{H}, \mathrm{SCH}_{2}\right), 3.62(\mathrm{dd}, J=6.9,2.2 \mathrm{~Hz}, 1 \mathrm{H}$, $\mathrm{SCH}), 2.84$ (ddd, $J=15.3,11.4,6.9 \mathrm{~Hz}, 1 \mathrm{H}, \mathrm{H}-5), 2.57$ (dt, $J=15.3$, $\left.2.2 \mathrm{~Hz}, 1 \mathrm{H}, \mathrm{CH}_{2}\right) .{ }^{13} \mathrm{C}$ NMR $\left(101 \mathrm{MHz}, \mathrm{CDCl}_{3}\right) \delta 145.8,143.6,134.5$, $131.1(\mathrm{q}, J=32.2 \mathrm{~Hz}), 130.2,130.0,129.2,128.6(2 \mathrm{C}), 128.3,127.6$ (2C), 127.2, 125.8, 125.7, $124.4(q, J=3.7 \mathrm{~Hz}), 124.0(q, J=273 \mathrm{~Hz})$, $123.4(\mathrm{q}, J=3.8 \mathrm{~Hz}), 65.7(\mathrm{NCH}), 49.4\left(\mathrm{CH}_{2}\right), 46.5(\mathrm{SCH}), 32.6\left(\mathrm{SCH}_{2}\right)$. ${ }^{19} \mathrm{~F}$ NMR $\left(376 \mathrm{MHz}, \mathrm{CDCl}_{3}\right) \delta-62.5$. HRMS (ESI-Q-TOF) $\mathrm{m} / \mathrm{z}$ calcd for $\mathrm{C}_{23} \mathrm{H}_{21} \mathrm{~F}_{3} \mathrm{NS}[\mathrm{M}+\mathrm{H}]^{+}:$400.1341, found: 400.1356 .

\section{4-(4-chlorophenyl)-2-phenyl-1,3,4,6-tetrahydro-2H-benzo $[c][1,5]$ thiazocine $(4 \mathrm{j})$}

Following the general procedure $A$, starting from substrate $\mathbf{3} \mathbf{j}$ (74 mg, $0.15 \mathrm{mmol}$ ), product $4 \mathrm{j}$ (14 mg, $0.04 \mathrm{mmol}, 25 \%$ ) has been obtained as a colorless oil. TLC (heptane/AcOEt 95/05, Rf $=0.16$ ).

Following the general procedure $B$, starting from substrate $3 \mathbf{j}$ $(60 \mathrm{mg}, 0.12 \mathrm{mmol})$, a mixture of products $4 \mathbf{j}$ and $\mathbf{4}^{\prime} \mathbf{j}(12 \mathrm{mg}$, $0.03 \mathrm{mmol}, 27 \%$, ratio $0.5: 1)$ have been obtained as a yellow oil. ${ }^{1} \mathrm{H}$ NMR $\left(400 \mathrm{MHz}, \mathrm{CDCl}_{3}\right) \delta$ 7.49-7.41 (m, 5H), 7.39-7.35 (m, 1H), 7.29$7.20(\mathrm{~m}, 6 \mathrm{H}), 6.97-6.94(\mathrm{~m}, 1 \mathrm{H}), 4.68\left(\mathrm{~d}, J=13.2 \mathrm{~Hz}, 1 \mathrm{H}, \mathrm{SCH}_{2}\right), 4.16$ (dd, $J=11.2,2.2 \mathrm{~Hz}, 1 \mathrm{H}, \mathrm{NCH}), 3.82\left(\mathrm{~d}, J=13.2 \mathrm{~Hz}, 1 \mathrm{H}, \mathrm{SCH}_{2}\right), 3.66$ (dd, J=7.0, $2.1 \mathrm{~Hz}, 1 \mathrm{H}, \mathrm{SCH}$ ), 2.90 (ddd, $J=15.3,11.2,7.0 \mathrm{~Hz}, 1 \mathrm{H}$, $\left.\mathrm{CH}_{2}\right), 2.58\left(\mathrm{dt}, J=15.3,2.1 \mathrm{~Hz}, 1 \mathrm{H}, \mathrm{CH}_{2}\right) .{ }^{13} \mathrm{C}$ NMR $\left(101 \mathrm{MHz} \mathrm{CDCl}_{3}\right) \delta$ $146.3,145.0,142.3,134.2,132.8,130.2,129.0$ (2C), 128.9 (2C), 128.7 (2C), 128.3, 127.7, $126.5(2 \mathrm{C}), 125.6,125.5,66.1(\mathrm{NCH}), 49.4\left(\mathrm{CH}_{2}\right)$, 46.0 (SCH), $32.7\left(\mathrm{SCH}_{2}\right)$. HRMS (ESI-Q-TOF) $\mathrm{m} / \mathrm{z}$ calcd for $\mathrm{C}_{22} \mathrm{H}_{21} \mathrm{CINS}$ $[\mathrm{M}+\mathrm{H}]^{+}: 366.1078$, found: 366.1084 .

\section{2-isopropyl-4-phenyl-1,3,4,6-tetrahydro-2H-benzo[c][1,5] thiazocine $(4 \mathrm{k})$}

Following the general procedure $A$, starting from substrate $3 \mathbf{k}$ (65 mg, $0.15 \mathrm{mmol}$ ), product $4 \mathrm{k}(17 \mathrm{mg}, 0.06 \mathrm{mmol}, 40 \%)$ has been obtained as a colorless oil. TLC (heptane/AcOEt 90/10, Rf $=0.38$ ).

Following the general procedure $B$, starting from substrate $\mathbf{3 k}$ (60 mg, $0.14 \mathrm{mmol}$ ), product $4 \mathrm{k}$ ( $22 \mathrm{mg}, 0.07 \mathrm{mmol}, 52 \%)$ has been obtained as a colorless oil. ${ }^{1} \mathrm{H}$ NMR $\left(500 \mathrm{MHz}_{1} \mathrm{CDCl}_{3}\right) \delta 7.21-7.08$ $(\mathrm{m}, 7 \mathrm{H}), 6.89(\mathrm{td}, J=7.5,1.4 \mathrm{~Hz}, 1 \mathrm{H}), 6.82(\mathrm{dd}, J=8.2,1.4 \mathrm{~Hz}, 1 \mathrm{H})$, $4.22\left(\mathrm{~d}, J=14.0 \mathrm{~Hz}, 1 \mathrm{H}, \mathrm{SCH}_{2}\right), 3.75\left(\mathrm{~d}, J=14.0 \mathrm{~Hz}, 1 \mathrm{H}, \mathrm{SCH}_{2}\right), 3.50$ (dd, $J=8.0,3.3 \mathrm{~Hz}, 1 \mathrm{H}, \mathrm{SCH}), 2.90-2.86(\mathrm{~m}, 1 \mathrm{H}, \mathrm{NCH}), 2.37-2.25(\mathrm{~m}$, $\left.2 \mathrm{H}, \mathrm{CH}_{2}\right), 1.78-1.68(\mathrm{~m}, 1 \mathrm{H}), 0.97\left(\mathrm{~d}, J=7.2 \mathrm{~Hz}, 3 \mathrm{H}, \mathrm{CH}_{3}\right), 0.96(\mathrm{~d}, J=$ $\left.7.2 \mathrm{~Hz}, 3 \mathrm{H}, \mathrm{CH}_{3}\right) .{ }^{13} \mathrm{C}$ NMR $\left(126 \mathrm{MHz}_{1} \mathrm{CDCl}_{3}\right) \delta 147.9,143.7,130.4$, $129.3,128.6(2 \mathrm{C}), 128.4,127.4(2 \mathrm{C}), 127.1,122.5,122.4,65.2(\mathrm{NCH})$, $48.5\left(\mathrm{CH}_{2}\right), 46.2(\mathrm{SCH}), 34.8,34.7,19.6\left(\mathrm{CH}_{3}\right), 18.0\left(\mathrm{CH}_{3}\right)$. HRMS (ESIQ-TOF) $\mathrm{m} / \mathrm{z}$ calcd for $\mathrm{C}_{19} \mathrm{H}_{24} \mathrm{NS}[\mathrm{M}+\mathrm{H}]^{+}: 298.1624$, found: 298.1640 .

\section{2-benzyl-4-phenyl-1,3,4,6-tetrahydro-2H-benzo[c][1,5] thiazocine (4I)}

Following the general procedure $B$, starting from substrate $3 \mathbf{I}$ ( $55 \mathrm{mg}, 0.12 \mathrm{mmol}$ ), product $4 \mathrm{l}$ ( $10 \mathrm{mg}, 0.03 \mathrm{mmol}, 25 \%$ ) has been obtained as a brown amorphous solid. TLC (heptane/AcOEt 90/10, $\mathrm{Rf}=0.33) .{ }^{1} \mathrm{H}$ NMR $\left(400 \mathrm{MHz}, \mathrm{CDCl}_{3}\right) \delta 7.40-7.34(\mathrm{~m}, 2 \mathrm{H}), 7.31-7.19$ $(\mathrm{m}, 9 \mathrm{H}), 7.10-7.05(\mathrm{~m}, 2 \mathrm{H}), 6.52-6.48(\mathrm{~m}, 1 \mathrm{H}), 4.45(\mathrm{~d}, J=13.2 \mathrm{~Hz}$, $\left.1 \mathrm{H}, \mathrm{SCH}_{2}\right), 3.68\left(\mathrm{~d}, J=13.2 \mathrm{~Hz}, 1 \mathrm{H}, \mathrm{SCH}_{2}\right), 3.55-3.47(\mathrm{~m}, 1 \mathrm{H}, \mathrm{SCH})$, $3.30-3.22(\mathrm{~m}, 1 \mathrm{H}, \mathrm{NCH}), 2.89-2.73(\mathrm{~m}, 2 \mathrm{H}), 2.54-2.48(\mathrm{~m}, 2 \mathrm{H}) .{ }^{13} \mathrm{C}$ NMR $\left(101 \mathrm{MHz}, \mathrm{CDCl}_{3}\right) \delta 146.7,143.9,138.7,133.7,130.1,129.3(2 \mathrm{C})$, $128.8(2 \mathrm{C}), 128.6(2 \mathrm{C}), 128.0,127.6(2 \mathrm{C}), 127.1,126.8,124.8,124.7$, $62.6,48.4,46.9,43.9,32.8$. HRMS (ESI-Q-TOF) $\mathrm{m} / \mathrm{z}$ calcd for $\mathrm{C}_{23} \mathrm{H}_{24} \mathrm{NS}$ $[\mathrm{M}+\mathrm{H}]^{+}: 346.1624$, found: 346.1627 .

\section{2-phenyl-2,3,4,4a,6,11,12,12a-octahydro-1 $H$-dibenzo[ $b, f][1,5]$} thiazocine $(4 \mathrm{~m})$

Following the general procedure $B$, starting from substrate $3 \mathrm{~m}$

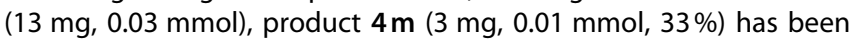
obtained as a colorless oil. TLC (heptane/AcOEt 90/10, $\mathrm{Rf}=0.30$ ). ${ }^{1} \mathrm{H}$ NMR $\left(400 \mathrm{MHz}, \mathrm{CDCl}_{3}\right) \delta 7.38-7.23(\mathrm{~m}, 5 \mathrm{H}), 7.06-6.98(\mathrm{~m}, 2 \mathrm{H}), 6.73$ (td, $J=7.4,1.4 \mathrm{~Hz}, 1 \mathrm{H}), 6.64$ (dd, $J=7.9,1.4 \mathrm{~Hz}, 1 \mathrm{H}$ ), 4.42 (bs, $1 \mathrm{H}$, $\mathrm{NCH}), 4.24\left(\mathrm{~d}, J=16.7 \mathrm{~Hz}, 1 \mathrm{H}, \mathrm{SCH}_{2}\right), 4.08\left(\mathrm{~d}, J=16.7 \mathrm{~Hz}, 1 \mathrm{H}, \mathrm{SCH}_{2}\right)$, 3.77 (bs, 1H, SCH), 3.34 (bs, $\left.1 \mathrm{H}, \mathrm{CH}_{2}\right), 2.25-2.18(\mathrm{~m}, 1 \mathrm{H}), 2.10$ (qd, $J=$ $13.2,3.7 \mathrm{~Hz}, 1 \mathrm{H}), 1.94(\mathrm{tt}, J=13.7,4.3 \mathrm{~Hz}, 1 \mathrm{H}), 1.85-1.76(\mathrm{~m}, 1 \mathrm{H})$, $1.67-1.61(\mathrm{~m}, 1 \mathrm{H}), 1.59-1.51(\mathrm{~m}, 1 \mathrm{H}), 1.46-1.36(\mathrm{~m}, 1 \mathrm{H}), 0.92-0.81$ 
(m, 1H). ${ }^{13} \mathrm{C}$ NMR $\left(101 \mathrm{MHz}, \mathrm{CDCl}_{3}\right) \delta 146.0,144.9,131.6,128.7(2 \mathrm{C})$, 128.1, 127.0, 126.2 (2C), 124.8, 120.6, 119.5, $61.4(\mathrm{NCH}), 54.2(\mathrm{SCH})$, 46.5, 40.5, $34.7\left(\mathrm{SCH}_{2}\right), 26.0,22.4,21.0$. HRMS (ESI-Q-TOF) $\mathrm{m} / \mathrm{z}$ calcd for $\mathrm{C}_{20} \mathrm{H}_{24} \mathrm{NS}[\mathrm{M}+\mathrm{H}]^{+}: 310.1624$, found: 310.1636 .

12-phenyl-2,3,4,4a,6,11,12,12a-octahydro- $1 \mathrm{H}$ 1,4-methanodibenzo[ $[b, f][1,5]$ thiazocine $(4 \mathrm{n})$

Following the general procedure $A$, starting from substrate $\mathbf{3 n}$ (50 $\mathrm{mg}, 0.11 \mathrm{mmol})$, product $4 \mathrm{n}(23 \mathrm{mg}, 0.07 \mathrm{mmol}, 64 \%)$ has been obtained as a colorless oil.

Following the general procedure $B$, starting from substrate $3 \mathbf{n}$ (60 $\mathrm{mg}, 0.13 \mathrm{mmol})$, product $4 \mathrm{n}(42 \mathrm{mg}, 0.13 \mathrm{mmol}, 98 \%)$ has been obtained as a colorless oil. Recrystallization in $\mathrm{CDCl}_{3}$ gave colorless crystals $\left(\mathrm{Mp}=155^{\circ} \mathrm{C}\right)$. TLC (heptane/AcOEt 95/05, Rf $=0.23$ ). ${ }^{1} \mathrm{H}$ NMR $\left(400 \mathrm{MHz} \mathrm{CDCl}_{3}\right) \delta 7.39(\mathrm{dd}, J=8.2,6.8 \mathrm{~Hz}, 2 \mathrm{H}), 7.34-7.25(\mathrm{~m}$, $3 \mathrm{H}), 7.13(\mathrm{dd}, J=7.2,1.9 \mathrm{~Hz}, 1 \mathrm{H}), 7.06-6.95(\mathrm{~m}, 2 \mathrm{H}), 6.75-6.21(\mathrm{~m}$, $1 \mathrm{H}), 4.44-4.22(\mathrm{bs}, 1 \mathrm{H}, \mathrm{NCH}), 3.94\left(\mathrm{~d}, J=14.0 \mathrm{~Hz}, 1 \mathrm{H}, \mathrm{SCH}_{2}\right), 3.84(\mathrm{~d}$, $\left.J=14.0 \mathrm{~Hz}, 1 \mathrm{H}, \mathrm{SCH}_{2}\right), 3.58(\mathrm{bs}, 1 \mathrm{H}, \mathrm{SCH}), 2.47-2.32(\mathrm{~m}, 2 \mathrm{H}), 1.65-$ $1.53(\mathrm{~m}, 3 \mathrm{H}), 1.38-1.24(\mathrm{~m}, 2 \mathrm{H}), 1.22-1.14(\mathrm{~m}, 1 \mathrm{H}), 0.93-0.87(\mathrm{~m}, 1 \mathrm{H})$. ${ }^{13} \mathrm{C}$ NMR $\left(101 \mathrm{MHz}, \mathrm{CDCl}_{3}\right) \delta 147.9,145.1,137.0,129.4,129.0(2 \mathrm{C})$, $127.7(2 \mathrm{C}), 127.3,127.1(2 \mathrm{C}), 124.6,123.8,68.7(\mathrm{NCH}), 59.2(\mathrm{SCH})$, $56.6\left(\mathrm{CH}_{2}\right), 45.0,40.2,35.7\left(\mathrm{SCH}_{2}\right), 34.9,30.4,28.3$.

\section{2-(p-tolyl)-2,3,4,4a,6,11,12,12a-octahydro- $1 \mathrm{H}$ -} 1,4-methanodibenzo $[b, f][1,5]$ thiazocine $(40)$

Following the general procedure $B$, starting from substrate 30 (100 $\mathrm{mg}, 0.22 \mathrm{mmol})$, product $4 \mathrm{o}(50 \mathrm{mg}, 0.15 \mathrm{mmol}, 69 \%)$ has been obtained as a colorless oil. TLC (heptane/AcOEt 90/10, Rf= 0.36).

${ }^{1} \mathrm{H}$ NMR $\left(400 \mathrm{MHz}, \mathrm{CDCl}_{3}\right) \delta 7.19(\mathrm{~d}, J=7.8 \mathrm{~Hz}, 2 \mathrm{H}), 7.15(\mathrm{~d}, J=$ $7.8 \mathrm{~Hz}, 2 \mathrm{H}), 7.11(\mathrm{dd}, J=7.2,1.8 \mathrm{~Hz}, 1 \mathrm{H}), 7.06-6.93(\mathrm{~m}, 2 \mathrm{H}), 6.51(\mathrm{~d}$, $J=7.5 \mathrm{~Hz}, 1 \mathrm{H}), 4.28(\mathrm{~d}, J=11.1 \mathrm{~Hz}, 1 \mathrm{H}, \mathrm{NCH}), 3.93(\mathrm{~d}, J=14.0 \mathrm{~Hz}, 1 \mathrm{H}$, $\left.\mathrm{SCH}_{2}\right), 3.82\left(\mathrm{~d}, J=14.0 \mathrm{~Hz}, 1 \mathrm{H}, \mathrm{SCH}_{2}\right), 3.56(\mathrm{bs}, 1 \mathrm{H}, \mathrm{SCH}), 2.44-2.30$ $(\mathrm{m}, 5 \mathrm{H}), 1.64-1.51(\mathrm{~m}, 3 \mathrm{H}), 1.37-1.23(\mathrm{~m}, 2 \mathrm{H}), 1.22-1.12(\mathrm{~m}, 1 \mathrm{H})$, 0.91-0.84 (m, 1H). ${ }^{13} \mathrm{C}$ NMR $\left(101 \mathrm{MHz}, \mathrm{CDCl}_{3}\right) \delta 147.9,142.0,136.8$, 136.7, $129.6(2 \mathrm{C}), 129.4,127.7(2 \mathrm{C}), 127.2,124.5,123.8,68.5(\mathrm{NCH})$, $58.9(\mathrm{SCH}), 56.6\left(\mathrm{CH}_{2}\right), 45.0,40.3,35.7\left(\mathrm{SCH}_{2}\right), 34.9,30.4,28.3,21.2$. HRMS (ESI-Q-TOF) $\mathrm{m} / z$ calcd for $\mathrm{C}_{22} \mathrm{H}_{26} \mathrm{NS}[\mathrm{M}+\mathrm{H}]^{+}: 336.1780$, found: 336.1805 .

12-(4-(trifluoromethyl)phenyl)-2,3,4,4a,6,11,12,12a-octahydro$1 H-1,4$-methanodibenzo $[b, f][1,5]$ thiazocine $(4 p)$

Following the general procedure $B$, starting from substrate $3 p$ $(53 \mathrm{mg}, 0.10 \mathrm{mmol})$, product $4 \mathrm{p}(21 \mathrm{mg}, 0.05 \mathrm{mmol}, 53 \%$, no epimerization) has been obtained as a white amorphous solid. TLC (heptane/AcOEt 95/05, Rf=0.28). ${ }^{1} \mathrm{H}$ NMR $\left(500 \mathrm{MHz}, \mathrm{CDCl}_{3}\right) \delta 7.58$ $(\mathrm{d}, J=8.0 \mathrm{~Hz}, 2 \mathrm{H}), 7.33(\mathrm{~d}, J=8.0 \mathrm{~Hz}, 2 \mathrm{H}), 7.05(\mathrm{dd}, J=7.1,1.8 \mathrm{~Hz}$, $1 \mathrm{H}), 6.98-6.90(\mathrm{~m}, 2 \mathrm{H}), 6.40(\mathrm{~d}, J=7.5 \mathrm{~Hz}, 1 \mathrm{H}), 4.26(\mathrm{~d}, J=11.2 \mathrm{~Hz}$, $1 \mathrm{H}, \mathrm{NCH}), 3.86\left(\mathrm{~d}, J=14.1 \mathrm{~Hz}, 1 \mathrm{H}, \mathrm{SCH}_{2}\right), 3.73(\mathrm{~d}, J=14.1 \mathrm{~Hz}, 1 \mathrm{H}$, $\left.\mathrm{SCH}_{2}\right), 3.53$ (bs, 1H, SCH), 2.37-2.27 (m, 2H), 1.60-1.42 (m, 3H), 1.31$1.15(\mathrm{~m}, 2 \mathrm{H}), 1.15-1.06(\mathrm{~m}, 1 \mathrm{H}), 0.88-0.84(\mathrm{~m}, 1 \mathrm{H}) .{ }^{13} \mathrm{C}$ NMR $\left(126 \mathrm{MHz}, \mathrm{CDCl}_{3}\right) \delta 149.0,147.5,137.5,129.4,129.4(\mathrm{q}, J=32.2 \mathrm{~Hz})$, 127.9 (2C), 127.7, 125.9 (q, J=3.8 Hz, 2C), 124.8, 124.3, $124.2(\mathrm{q}, J=$ $272 \mathrm{~Hz}), 68.3(\mathrm{NCH}), 59.4(\mathrm{SCH}), 56.8\left(\mathrm{CH}_{2}\right), 45.1,39.9,36.0\left(\mathrm{SCH}_{2}\right)$, 34.8, 30.3, 28.3. ${ }^{19} \mathrm{~F}$ NMR (376 MHz, $\mathrm{CDCl}_{3}$ ) $\delta$ 62.4. HRMS (ESI-Q-TOF) $\mathrm{m} / z$ calcd for $\mathrm{C}_{22} \mathrm{H}_{23} \mathrm{~F}_{3} \mathrm{NS}[\mathrm{M}+\mathrm{H}]^{+}: 390.1498$, found: 390.1499 . 12-(3-(trifluoromethyl)phenyl)-2,3,4,4a,6,11,12,12a-octahydro$1 H-1,4-$ methanodibenzo[ $b, f][1,5]$ thiazocine $(4 q)$

Following the general procedure $B$, starting from substrate $3 \mathbf{q}$ $(100 \mathrm{mg}, 0.19 \mathrm{mmol})$, product $4 \mathrm{q}(40 \mathrm{mg}, 0.10 \mathrm{mmol}, 53 \%)$ has been obtained as a white amorphous solid. TLC (heptane/AcOEt 90/10, $\mathrm{Rf}=0.46) .{ }^{1} \mathrm{H}$ NMR $\left(400 \mathrm{MHz}, \mathrm{CDCl}_{3}\right) \delta$ 7.63-7.46 (m, 4H), 7.13 $(\mathrm{dd}, J=7.2,1.9 \mathrm{~Hz}, 1 \mathrm{H}), 7.09-6.96(\mathrm{~m}, 2 \mathrm{H}), 6.48(\mathrm{dd}, J=7.4,1.6 \mathrm{~Hz}$, $1 \mathrm{H}), 4.33(\mathrm{~d}, J=11.1 \mathrm{~Hz}, 1 \mathrm{H}, \mathrm{NCH}), 3.93\left(\mathrm{~d}, J=14.3 \mathrm{~Hz}, 1 \mathrm{H}, \mathrm{SCH}_{2}\right)$, $3.82\left(\mathrm{~d}, J=14.3 \mathrm{~Hz}, 1 \mathrm{H}, \mathrm{SCH}_{2}\right), 3.59$ (bs, $\left.1 \mathrm{H}, \mathrm{SCH}\right), 2.44-2.34(\mathrm{~m}, 2 \mathrm{H})$, 1.71-1.51 (m, 3H), 1.41-1.25 (m, 2H), 1.23-1.13 (m, 1H), 1.00-0.91 $(\mathrm{m}, 1 \mathrm{H}) .{ }^{13} \mathrm{C}$ NMR $\left(101 \mathrm{MHz}, \mathrm{CDCl}_{3}\right) \delta 147.5,146.1,137.3,131.2$ (q, $J=32.3 \mathrm{~Hz}), 130.8,129.3(2 \mathrm{C}), 127.9,124.8,124.3(2 \mathrm{C}), 124.2(\mathrm{q}, J=$ $272 \mathrm{~Hz}), 124.0(\mathrm{q}, J=3.8 \mathrm{~Hz}), 68.2(\mathrm{NCH}), 56.9(\mathrm{SCH}), 45.1,39.9,36.1$ $\left(\mathrm{SCH}_{2}\right), 34.9,30.2,28.3 .{ }^{19} \mathrm{~F}$ NMR $\left(376 \mathrm{MHz}, \mathrm{CDCl}_{3}\right) \delta$ 62.4. HRMS (ESIQ-TOF) $\mathrm{m} / \mathrm{z}$ calcd for $\mathrm{C}_{22} \mathrm{H}_{23} \mathrm{~F}_{3} \mathrm{NS} \quad[\mathrm{M}+\mathrm{H}]^{+}: 390.1498$ found: 390.1506 .

\section{2-(4-bromophenyl)-2,3,4,4a,6,11,12,12a-octahydro- $1 \mathrm{H}$ - 1,4-methanodibenzo[b,f][1,5]thiazocine $(4 r)$}

Following the general procedure $B$, starting from substrate $3 \mathbf{r}$ ( $80 \mathrm{mg}, 0.15 \mathrm{mmol})$, product $4 \mathrm{r}(31 \mathrm{mg}, 0.08 \mathrm{mmol}, 51 \%)$ has been obtained as a colorless oil. TLC (heptane/AcOEt 90/10, Rf $=0.35$ ). ${ }^{1} \mathrm{H}$ NMR $\left(400 \mathrm{MHz}, \mathrm{CDCl}_{3}\right) \delta 7.52(\mathrm{~d}, J=8.6 \mathrm{~Hz}, 2 \mathrm{H}), 7.17(\mathrm{~d}, J=7.9 \mathrm{~Hz}$, $2 \mathrm{H}), 7.12(\mathrm{dd}, J=7.3,1.8 \mathrm{~Hz}, 1 \mathrm{H}), 7.09-6.95(\mathrm{~m}, 2 \mathrm{H}), 6.50$ (dd, $J=7.4$, $1.5 \mathrm{~Hz}, 1 \mathrm{H}), 4.24(\mathrm{~d}, J=11.1 \mathrm{~Hz}, 1 \mathrm{H}, \mathrm{NCH}), 3.92(\mathrm{~d}, J=14.0 \mathrm{~Hz}, 1 \mathrm{H}$, $\left.\mathrm{SCH}_{2}\right), 3.80\left(\mathrm{~d}, J=14.0 \mathrm{~Hz}, 1 \mathrm{H}, \mathrm{SCH}_{2}\right), 3.58$ (bs, $\left.1 \mathrm{H}, \mathrm{SCH}\right), 2.43-2.28$ $(\mathrm{m}, 2 \mathrm{H}), 1.70-1.47(\mathrm{~m}, 3 \mathrm{H}), 1.42-1.25(\mathrm{~m}, 2 \mathrm{H}), 1.21-1.12(\mathrm{~m}, 1 \mathrm{H})$, 0.99-0.89 (m, 1H). ${ }^{13} \mathrm{C}$ NMR $\left(101 \mathrm{MHz}, \mathrm{CDCl}_{3}\right) \delta$ 147.7, 144.1, $137.1,132.0$ (2C), 129.4, 129.1, $127.8(2 \mathrm{C}), 124.7,124.1,120.9,68.1$ ( $\mathrm{NCH}), 59.3(\mathrm{SCH}), 56.8\left(\mathrm{CH}_{2}\right), 45.1,40.0,36.0\left(\mathrm{SCH}_{2}\right), 34.8,30.3,28.3$. HRMS (ESI-Q-TOF) $\mathrm{m} / \mathrm{z}$ calcd for $\mathrm{C}_{21} \mathrm{H}_{21} \mathrm{BrNS}[\mathrm{M}+\mathrm{H}]^{+}:$398.0573, found: 398.0582 .

Deposition Numbers 2042277 (for 4 b), 2056458(for 4 e), 2042276 (for 4f), and 2042275 (for 4n) contain the supplementary crystallographic data for this paper. These data are provided free of charge by the joint Cambridge Crystallographic Data Centre and Fachinformationszentrum Karlsruhe Access Structures service www.ccdc.cam.ac.uk/structures

\section{Acknowledgements}

This work of the Interdisciplinary Thematic Institute InnoVec, as part of the ITI 2021-2028 program of the University of Strasbourg, CNRS and Inserm, was supported by IdEx Unistra (ANR-10-IDEX0002) and SFRI-STRAT'US project (ANR-20-SFRI-0012) under the framework of the French Investments for the Future Program. The doctoral grant for M.C. was financed by the "Ministère de I'Enseignement Supérieur, de la Recherche et de I'Innovation". We thank Delphine Garnier, Estefania Oliva (PACSI, GDS 3670), and Stéphanie Coutin (FR2010) for NMR analyzes and HRMS measurements, Lydia Karmazin and Corinne Bailly (GDS 3648) for X-ray analyses, Kim Gaudin and Fabian Schlimpen (master students 2018-2019) for helpful experiments.

\section{Conflict of Interest}

The authors declare no conflict of interest. 
Keywords: Copper - Heterocycles - Homogeneous catalysis . Intramolecular N-arylation · Synthetic methods

[1] See for example: a) M. E. Maier, Angew. Chem. Int. Ed. 2000, 39, 20732077; Angew. Chem. 2000, 112, 2153-2157; b) L. Yet, Tetrahedron 1999, 55, 9349-9403; c) G. A. Molander, Acc. Chem. Res. 1998, 31, 603-609; d) J. R. Donald, W. P. Unsworth, Chem. Eur. J. 2017, 23, 8780-8799; e) L. Yet, Chem. Rev. 2000, 100, 2963-3007; f) K. C. Majumdar, RSC Adv. 2011, 1, 1152-1170; g) M. Choury, A. Basilio Lopes, G. Blond, M. Gulea, Molecules 2020, 25, 3147; h) R. L. Reyes, T. Iwai, M. Sawamura, Chem. Rev. doi: 10.1021/acs.chemrev.0c00793.

[2] See, for example: a) G. Campiani, V. Nacci, I. Fiorini, M. P. De Filippis, A. Garofalo, S. M. Ciani, G. Greco, E. Novellino, C. Manzoni, T. Mennini, Eur. J. Med. Chem. 1997, 32, 241-251; b) S. Miyamoto, M. Yoshimoto, Chem. Pharm. Bull. 1985, 33, 4856-4864; c) S. Miyamoto, M. Yoshimoto, Chem. Pharm. Bull. 1986, 33, 694-700; d) F. Bertha, G. Hornyák, K. Zauer, A Feller, K. Lempert, E. Pjecka, G. Tóth, Tetrahedron 1985, 41, 2855-2860; e) Y. Pei, M. J. Lilly, D. J. Owen, L. J. D'Souza, X. Q. Tang, J. Yu, R. Nazarbaghi, A. Hunter, C. M. Anderson, S. Glasco, N. J. Ede, I. W. James, U. Maitra, S. Chandrasekaran, W. H. Moos, S. S. Ghosh, J. Org. Chem. 2003, 68, 92-98; f) B. E. Fink, A. V. Gavai, J. S. Tokarski, B. Goyal, R. Misra, H.-Y. Xiao, S. D. Kimball, W.-C. Han, D. Norris, T. E. Spires, D. You, M. M. Gottardis, M. V. Lorenzi, G. D. Vite, Bioorg. Med. Chem. Lett. 2006, 16, 1532-1536; g) J. Gante, R. Weitzel, Tetrahedron Lett. 1998, 29, 181-184; h) A. Rolfe, G. H. Lushington, P. R. Hanson, Org. Biomol. Chem. 2010, 8, 2198-2203.

[3] a) M. Feng, B. S. Tang, H. Liang, X. Jiang, Curr. Top. Med. Chem. 2016, 16, 1200-1216; b) K. A. Scott, J. T. Njardarson, Top. Curr. Chem. 2018, 376:5 https://doi.org/10.1007/s41061-018-0184-5.

[4] See, for example: a) H. Yale, F. Sowinski, E. Spitzmiller, J. Heterocycl. Chem. 1972, 9, 899-909; b) H. Sashida, T. Tsuchiya, Heterocycles 1984, 22, 1303-1306; c) H. J. Federsel, G. Glassare, K. Hogstrom, J. Wiestal, B. Zinko, C. Odman, J. Org. Chem. 1995, 60, 2597-2606.

[5] a) H. A. K. Abd El-Aal, Arkivoc 2018, 3, 45-61; b) H. A. K. Abd El-Aal, A. A. Khalaf, Arkivoc 2019, 6, 212-227; c) J. B. Press, N. H. Eudy, J. Org. Chem. 1984, 49, 116-122; d) M. Uskokovic, G. Grethe, J. lacobelli, W. Wenner, J. Org. Chem. 1965, 30, 3111-3114.

[6] C. Mukherjee, E. Biehl, Heterocycles 2004, 63, 2309-2318.

[7] L. Fodor, P. Csomós, A. Csámpai, P. Sohár, T. Holczbauer, A. Kálmán, Tetrahedron Lett. 2011, 52, 592-594.

[8] S. M. Lu, H. Alper, J. Am. Chem. Soc. 2005, 127, 14776-14784.

[9] A. Basilio Lopes, P. Wagner, M. Gulea, Eur. J. Org. Chem. 2019, 13611370.
[10] a) F. Lovering, J. Bikker, C. Humblet, J. Med. Chem. 2009, 52, 6752-6756; b) F. Lovering, MedChemComm 2013, 4, 515-519; c) M. Aldeghi, S. Malhotra, D. L. Selwood, A. W. E. Chan, Chem. Biol. Drug Des. 2014, 83, 450-461.

[11] a) J. Bariwal, E. Van der Eycken, Chem. Soc. Rev. 2013, 42, 9283-9303; b) S. Bhunia, G. G. Pawar, S. V. Kumar, Y. Jiang, D. Ma, Angew. Chem. Int. Ed. 2017, 56, 16136-16179; Angew. Chem. 2017, 129, 16352-16397; c) D. S. Surry, S. L. Buchwald, Chem. Sci. 2010, 1, 13-31; d) Y. Jiang, D. $\mathrm{Ma}$ in Copper-Mediated Cross-Coupling Reactions (Eds.: G. Evano, N. Blanchard), John Wiley \& Sons: Hoboken, NJ, USA, 2014, pp. 3-37.

[12] a) J. L. Kenwright, W. R. J. D. Galloway, D. T. Blackwell, A. Isidro-Llobet, J. Hodgkinson, L. Wortmann, S. D. Bowden, M. Welch, D. R. Spring, Chem. Eur. J. 2011, 17, 2981-2986; b) T. Yang, C. Lin, H. Fu, Y. Jiang, Y. Zhao, Org. Lett. 2005, 7, 4781-4784; c) V. Srinivasulu, K. D. Janda, I. A. AbuYousef, M. J. O'Connor, T. H. Al-Tel, Tetrahedron 2017, 73, 2139-2150.

[13] a) F. Peudru, F. Le Cavelier, J.-F. Lohier, M. Gulea, V. Reboul, Org. Lett. 2013, 15, 5710-5713; b) V. Snieckus, J. Panteleev, Synfacts 2014, 10, 0136-013; c) F. Peudru, F. Le Cavelier, J.-F. Lohier, V. Reboul, M. Gulea, Tetrahedron 2012, 68, 9016-9022.

[14] For Cu-catalyzed hydrodehalogenation, see for example: a) K. A. Cannon, M. E. Geuther, C. K. Kelly, S. Lin, A. H. Roy MacArthur, Organometallics 2011, 30, 4067-4073; b) P. S. Fier, J. F. Hartwig, J. Am. Chem. Soc. 2012, 134, 10795-10798.

[15] When the bromo-derivative of $\mathbf{3 a}$ was used ( $\mathrm{Br}$ instead I), hydrodebromination also occurred to give $5 \mathbf{a}$.

[16] C-T. Yang, Y. Fu, Y.-B. Huang, J. Yi, Q.-X. Guo, L. Liu, Angew. Chem. Int. Ed. 2009, 48, 7398-7401; Angew. Chem. 2009, 121, 7534-7537.

[17] a) Q. A. Lo, D. Sale, D. C. Braddock, R. P. Davies, ACS Catal. 2018, 8, 101109; b) S. Sung, D. Sale, D. C. Braddock, A. Armstrong, C. Brennan, R. P. Davies, ACS Catal. 2016, 6, 3965-3974; c) Q. A. Lo, D. Sale, D.C. Braddock, R. P. Davies, Eur. J. Org. Chem. 2019, 1944-1951.

[18] We assume that the major stereoisomer of $1 \mathbf{b}^{*}$ has the absolute configuration $(4 S, 6 R)$ as determined in ref [13a].

[19] a) J. A. Dale, D. L. Dull, H. S. Mosher, J. Org. Chem. 1969, 34, 9, $2543-$ 2549; b) D. A. Allen, A. E. Jr. Tomaso, O. P. Priest, D. F. Hindson, J. L. Hurlburt, J. Chem. Educ. 2008, 85, 698-700.

[20] a) J. Omelanczuk, M. Mikolajczyk, Tetrahedron: Asymmetry 1996, 7, 2687-2694; b) V. H. Vu, F. Louafi, N. Girard, R. Marion, T. Roisnel, V. Dorcet, J.-P. Hurvois, J. Org. Chem. 2014, 79, 3358-3373.

Manuscript received: March 13, 2021

Revised manuscript received: March 24, 2021

Accepted manuscript online: March 26, 2021 